\title{
Population dynamics and natural hazard risk management: conceptual and practical linkages for the case of Austrian policy making
}

\author{
Christoph Clar ${ }^{1,3}$ (D) Lukas Löschner ${ }^{2} \cdot$ Ralf Nordbeck $^{3} \cdot$ Tatjana Fischer $^{2}$. \\ Thomas Thaler ${ }^{1}$
}

Received: 28 February 2020 / Accepted: 10 October 2020 / Published online: 24 October 2020

(C) The Author(s) 2020

\begin{abstract}
This contribution explores the conceptual and empirical linkages between population dynamics and natural hazard risk management (NHRM). Following a review of the international scholarly literature, we conduct a mixed-methods approach in Austria, combining an online survey among policy makers and other stakeholders with a thematic analysis of policy documents. The aim is to investigate the practical relevance of socio-demographic change in Austria's NHRM. The study shows that many hazard-prone regions in Austria face population change, in particular demographic ageing and population decline. In addition, our findings from the online survey demonstrate the relevance of population dynamics in NHRM, especially with regard to hazard response and recovery. Nonetheless, policy formulation in NHRM overwhelmingly disregards demographic change as a relevant factor. Accordingly, the study underscores the importance of future-oriented risk management strategies to better account for ongoing and expected socio-demographic changes.
\end{abstract}

Keywords Demographic change $\cdot$ Population dynamics $\cdot$ Natural hazards $\cdot$ Risk management $\cdot$ Disaster risk

Christoph Clar

christoph.clar@boku.ac.at

1 Department of Civil Engineering and Natural Hazards, Institute of Mountain Risk Engineering, University of Natural Resources and Life Sciences, Vienna (BOKU), Peter-Jordan-Strasse 82, 1190 Vienna, Austria

2 Department of Landscape, Institute of Spatial Planning, Environmental Planning and Land Rearrangement, Spatial and Infrastructure Sciences, University of Natural Resources and Life Sciences, Vienna (BOKU), Peter-Jordan-Strasse 82, 1190 Vienna, Austria

3 Department of Economics and Social Sciences, Institute of Forest, Environmental, and Natural Resource Policy, University of Natural Resources and Life Sciences, Vienna (BOKU),

Feistmantelstrasse 4, 1180 Vienna, Austria 


\section{Introduction}

Hydro-meteorological events, including storms, floods, or landslides, globally account for the largest share of the reported economic losses due to natural hazards (Munich Re 2019). In recent years, extreme weather- and climate-related events caused severe damage in different parts of the world-notable examples include the riverine floods in Central Europe (2002), in the UK (2007), and in Southeast Asia (2014-15) or the recent tropical cyclone Idai in Eastern Africa (2019). Apart from the likely effects of climate change (Blöschl et al. 2019; IPCC 2012; Madsen et al. 2014), land use change, often in combination with environmental degradation (e.g. of protective mangrove forests), and in particular settlement growth and land development in hazard areas, has been identified as key drivers for these events and their disastrous impacts (Jongman et al. 2012; Pesaresi et al. 2017).

The dynamics underlying the changing levels of risks (Di Baldassarre et al. 2013; Merz et al. 2010; Paprotny et al. 2018) and the consequences of these developments for futureoriented risk management are well documented (cf. Allen et al. 2011; Evans et al. 2006; Nordbeck et al. 2019). Related studies, however, usually investigate the impact of population growth on future levels of risk and the policy options to anticipate and adapt risk management strategies (Cammerer and Thieken 2013; Löschner et al. 2017), while population decline-a demographic phenomenon in fact faced by many rural but also urban areas outside the booming agglomeration regions (CoR 2016), has remained outside the scientific and policy focus.

Generally speaking, the notion of population dynamics, i.e. changes in the size and structure of human populations, has been strikingly disregarded in relation to natural hazards research and risk management. Although a large body of the literature explores demographic determinants and their influence on the vulnerability of individuals and communities to natural hazards (e.g. Cutter and Finch 2008; Fekete 2009, 2018; Birkmann et al. 2015), surprisingly little is known about the policy side. In order to provide a comprehensive picture of the challenges natural hazard risk management (NHRM) is facing, it would be important to know to what extent policy makers and practitioners actually consider and account for long-term demographic and population changes.

Given the long-term commitments in NHRM to mitigate disaster-related damage and reduce the vulnerabilities to such events (Hallegatte 2009), and against the call for a more integrated and dynamic perspective on hazard risks and their management (Cutter and Emrich 2006; Cutter and Finch 2008; Kuhlicke 2010; Lutz and Muttarak 2017; Clar 2019), there arises the need for a more systematic, holistic and long-term oriented analysis of population dynamics and their implications for policy making in NHRM. As we will see below, population dynamics are being discussed in and integrated into various policy areas in Austria. We want to examine whether NHRM is one of them.

In this light, the paper pursues two aims. For one, it aims to conceptualise and systematise the interlinkages between population dynamics and NHRM and, based on the examination of one particular country (Austria), explore whether and how these interlinkages are considered in NHRM policies. Our research is thus guided by the following overarching questions:

- Which challenges are population dynamics imposing/expected to impose on NHRM in Austria?

- How are these challenges, and underlying developments, reflected in Austria's current NHRM policies? 
The paper addresses these questions based on an online survey among major policy actors in Austria's NHRM and a thematic analysis of policy documents. While the first step allows to assess the actual relevance of population dynamics for current and future NHRM, the second step provides insights into recent policy developments and questions whether actual and expected demographic changes are reflected therein. We chose Austria as our study area for three reasons: First, Austria is located along the Alpine ridge and, thus, prone to multiple mountain hazards (such as torrential floods, debris flows, landslides, rock fall or avalanches). With a high concentration of vulnerable land uses in the valleys, the country recurrently suffers damage from such weather- and climate-related events, in particular river flooding, which affected large parts of the country in 2002, 2005 and 2013 (Fuchs et al. 2015; 2017). Second, Austria has a long tradition in NHRM and, following recent extreme events, is pursuing a policy shift from hazard defence to a more integrated approach to risk management, which also aims to consider the human and societal influences on changing levels of risk (Fuchs et al. 2017; Löschner 2018; Thaler et al. 2017). Third, the population dynamics briefly mentioned above are particularly evident in Austria: (i) The country's population is rapidly ageing in all parts of Austria; (ii) overall population growth is unevenly distributed with many mountainous and rural areas outside the major agglomerations and tourism regions facing population decline; (iii) urban and rural areas alike show changes in the structure and composition of households; (iv) Austrian society, especially in urban areas, has become more ethnically and culturally diverse due to international migration. In sum, this makes Austria a particularly interesting case to explore the interrelations between population dynamics and NHRM.

The paper is organised as follows: In Sect. 2, we provide a brief overview of the interlinkages between various demographic factors and NHRM that can be found in academic literature. In Sect. 3, we outline the research design, develop the conceptual framework, introduce our case study and present the materials and methods. In Sect. 4, we summarise the results of the online survey among actors of the Austrian NHRM community as well as the findings from the thematic analysis of policy documents. In Sect. 5, we discuss the main findings of our case study, compare them to the scientific state-of-the-art and evaluate our conceptual framework. Finally, in Sect. 6, we draw our main conclusions.

\subsection{Interlinkages between demographic dynamics and the management of natural hazard risks}

A wealth of literature explores the links between various demographic factors and the management of hydro-meteorological hazard risks. Especially since Hurricane Katrina in 2005, several scholars examined changes following natural hazards, such as population movement or property quality (Paxson and Rouse 2008; Graif 2016; Lee 2018; Fekete 2018; Hauer et al. 2019). However, as a comprehensive review preceding and preparing this study shows, recently also the other side of the same coin, namely the impacts of demographic changes onto vulnerabilities and capacities to manage natural hazard risks have received increasing attention (Clar 2019). From a global perspective, demographic dynamics, for one, refer to the population ageing trend, which is evident in nearly every country in the world (UN 2015). Secondly, against the importance of spatio-temporal dynamics of risk, the notion of population dynamics also includes the spatial patterns of population change: While urban areas and metropolitan regions are generally experiencing population growth, many peripheral, rural or post-industrial areas face long-term population decline, such as mountain communities (CoR 2016). Third, the structure and composition of households 
are changing, as becomes especially evident in the trend towards smaller household sizes (Bonin 2013). Finally, as population growth, in particular in Western societies, is mainly driven by international migration, population dynamics are also characterised by the changing cultural and ethnic composition of a population in the destination areas (UN 2015).

Publications that provide insights into determining factors such as socio-economic status, age, migration, residency status, mobility, gender and gender relations, education, knowledge, religion and beliefs, disabilities and special needs establish the link between these factors and NHRM (Table 1). ${ }^{1}$

As the examination of the literature we reviewed suggests, these factors are strongly interdependent. This makes it even more difficult to assess their actual impact on NHRM and calls for approaches that apply a broader, more comprehensive perspective. If we dig deeper, it also becomes obvious that most of the studies that are mentioned apply a very static perspective (Clar 2019). They usually focus on the relevance of one or only a few particular demographic characteristics in one particular moment,for instance in the moment a flood arrives. However, some more recent contributions to the NHRM literature published in the last decade go one step further to address demographic change (e.g. the changing composition and size of a population) as a dynamic that can affect vulnerability, resilience and coping capacities in the long term (Adger 2000; Cross 2001; Wisner et al. 2003; Chakraborty et al. 2005; McLennan and Birch 2005; Fabricius et al. 2007; Cutter and Finch 2008; Donner and Rodríguez 2008; Fekete 2009a and 2009b; Gissing et al. 2010; McLeman 2010; Jiang and Hardee 2011; Amundsen 2012; Aubrecht et al. 2013; Roth et al. 2014; Birkmann et al. 2015; Dressler et al. 2016; Fekete et al. 2016; Fekete 2018). Their call for (more) dynamic perspectives on hazard risks and their management (Cutter and Emrich 2006; Cutter and Finch 2008; Kuhlicke 2010; Lutz and Muttarak 2017; Clar 2019) confirms that we still lack holistic approaches, which can serve as a model for systematic analyses of population dynamics in the frame of NHRM. This article aims to support the development of such approaches.

\section{Research design}

\subsection{Conceptual framework: linking population dynamics and natural hazard risk management}

In this section, we conceptualise the interlinkages between population dynamics and NHRM and operationalise the main linkages for our study. We begin with a definition of the underlying terms and then proceed with an operationalisation of the analytical dimensions.

Generally speaking, demography is the study of human populations, regarding changes in population numbers, as a result of natural population change (births/deaths) and net migration (immigrant/emigrants) as well as changes in the structure and demographic constituents of a given population, predominately age (OECD 2019). In this study we use the overarching term "population dynamics" (Thomlinson 1965) to delineate four procedural components of demographic change. This includes, first and foremost, the phenomenon of population ageing (or demographic ageing), which means

${ }^{1}$ For a comprehensive and detailed overview see Clar (2019). 


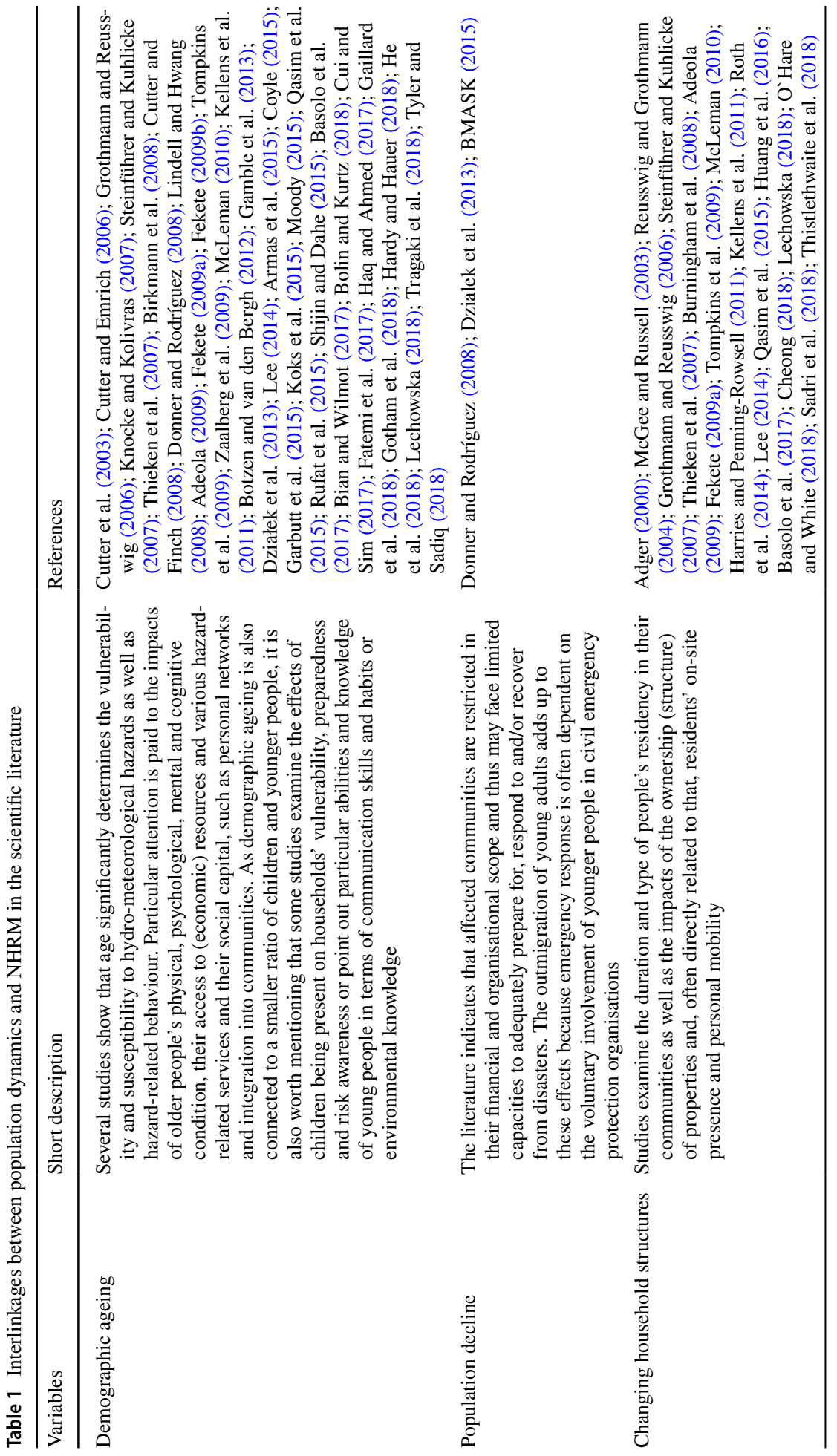




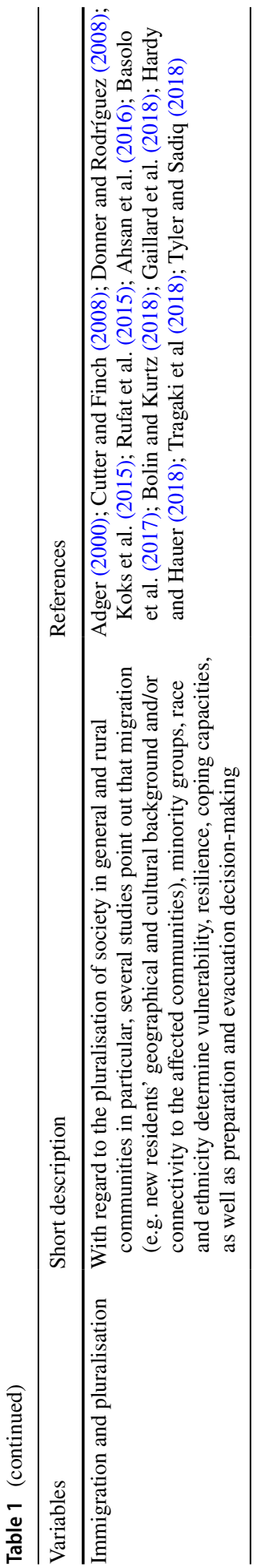


the increasing share of older persons, a demographic trend that is "virtually [affecting] every country in the world" and which "is poised to become one of the significant social transformations of the twenty-first century, with implications for nearly all sectors of society" (UN 2015, 1). Second, as highlighted inter alia in a recent report by the European Committee of Regions, population change often manifests itself in a spatial polarisation with an increasing population concentration in urban and metropolitan centres (mainly due to international and national population movements), while many rural, peripheral regions face population decline as a result of long-term low fertility rates and selective rural out-migration (CoR 2016). In this regard, a further constituent of population dynamics concerns international migration and the resulting pluralisation of society, for instance regarding more diverse cultural and ethnic backgrounds of a population. In countries with low birth rates, immigration is the main driver of population growth. However, immigration is overwhelmingly (but not exclusively) targeted towards urban areas, while remote, structurally weak rural areas generally have a lower share of foreign nationals, with the exception of tourist regions, which attract (low cost) foreign workers (CoR 2016). Finally, in this study, we also include in the understanding of population dynamics the phenomenon of changing household structures, which become evident inter alia in the trends of decreasing average household sizes, increasing rates of second-home ownership and a growing number of people who commute between their place of residence and work (OECD 2016).

We conceptually link the above-mentioned dimensions of population dynamics with the disaster risk management cycle in an effort to develop a more comprehensive and systematic understanding of the socio-demographic framework conditions for NHRM. While traditional mitigation measures build on the assumption that hydro-meteorological hazards (e.g. floods, landslides or avalanches) can be controlled solely by engineering solutions (such as levees, locks or barriers), NHRM acknowledges the need to reduce the severity of and the vulnerability to natural hazards based on a portfolio of approaches, comprising technical as well as non-structural (planning) and organisational measures (Klijn et al. 2008; Thieken et al. 2016; van Herk et al. 2015). We refer to risk management cycles, which propose the following three phases (BABS 2014; Kienholz et al. 2004; Poljanšek et al. 2017):

1. Preparedness: Preparedness focuses on the reduction of the vulnerability of people, property and other assets to natural hazards. It consists of prevention, such as technical solutions (to reduce the impact of hazards) and planning measures (to mitigate the accumulation of vulnerable assets in hazard areas), as well as emergency provisions, including warning and alert systems or emergency planning.

2. Response: Response includes all measures taken by public authorities, emergency organisations, private actors and other stakeholders to save lives and reduce damage and harm caused from natural hazards. In addition to emergency response and rescue operations, this phase also includes immediate measures to recondition and restore affected infrastructure (energy, transport, communication).

3. Recovery: During the recovery phase, damage is repaired, destroyed infrastructure and services are restored, and buildings are reconstructed. New standards and procedures may be developed to improve mitigation standards and preparedness for future hazard events. 
Table 2 Number of contacted survey participants and the respective response rate according to the respondents' sectoral self-affiliation

\begin{tabular}{llll}
\hline & Contacted & \multicolumn{2}{l}{ Response } \\
\cline { 3 - 4 } & Total & Number & Rate \\
\hline Water management & 23 & 12 & $52.1 \%$ \\
Torrent and avalanche control & 8 & 4 & $50.0 \%$ \\
Spatial planning & 20 & 9 & $45.0 \%$ \\
Civil protection & 11 & 7 & $63.6 \%$ \\
Emergency services & 46 & 18 & $39.1 \%$ \\
Other & - & 3 & - \\
Total & 108 & 53 & $49.1 \%$ \\
\hline
\end{tabular}

Overall, the combination of the above-mentioned demographic factors with these three stages provides a comprehensive overview of potential interlinkages and, thus, the perfect groundwork for our following analysis.

\subsection{Materials and methods}

This paper applies a conceptual framework that aims to examine the consideration of demographic change in NHRM by investigating the interlinkages between population dynamics and NHRM in Austria. We use a mixed-methods approach that combines a survey among hazards professionals with a thematic analysis of policy documents. First, we used the survey application LimeSurvey $($ ) to conduct an online survey among Austrian policy makers and leading actors from different policy sectors in NHRM. We started by selecting representatives of public bodies and organisations that were mentioned as main actors on the website of the department that is responsible for the crisis and disaster management within the Federal Ministry of the Interior. ${ }^{2}$ Then we added further actors in a snowball-like approach-based on recommendations of other experts and peers. Given the federalist structure of Austria's administrative system we invited leading policy makers (heads of units) from the federal and the state level that are relevant for NHRM in Austria. In addition, we invited personnel engaged in Austria's main emergency services in NHRM, such as the Red Cross, fire brigade associations or the mountain rescue service ${ }^{3}$ (see Table 2), again at the federal and the state level, to complete the survey.

The online survey was active for a 2-week period, from 18 to 30 June 2018. To maximise the response rate, which is regarded as one of the major limitations of online surveys (Evans and Mathur 2005), all survey participants received a personalised email invitation for the standardised questionnaire. In total, 53 of 108 invited persons completed the survey, producing a very good response rate of $49 \%$. The distribution by organisational background in the sample shows stronger population segments of members of the blue light organisations, such as fire brigades, Red Cross, who are overrepresented as there is a longer debate within the blue light organisations about socio-demographic challenges, such as language,

\footnotetext{
${ }^{2}$ https://www.bmi.gv.at/204/SKKM/start.aspx; accessed at 9/3/2020.

3 We included all actors in our survey who are listed as relevant actors on the webpage of the national crisis and disaster protection management (SKKM), which is part of the Austrian Federal Ministry of the Interior (cf. https://www.bmi.gv.at/204/skkm/start.aspx; accessed at 1/17/2019).
} 
age, in the case of emergency. The online survey investigated the thematic interlinkages between the four demographic factors of population dynamics and NHRM. The principal aim of the survey was to gain a better understanding of current and future practical challenges in NHRM related to population dynamics, to capture policy makers' perceptions of demographic issues in NHRM and to obtain their assessment of how/whether these issues are addressed in current NHRM policies. Accordingly, the survey consisted of a combination of closed questions $(n=14)$ and open-ended questions $(n=7)$. The survey was organised in three parts: First, respondents were asked to provide their professional information, in particular concerning their field of work, responsibilities, experience and academic background. The second part of the survey consisted of questions asking respondents to evaluate the general relevance of the four factors of population dynamics for NHRM in Austria. In the third part, finally, we asked respondents to specifically assess the relevance of the different demographic factors for the three phases of the risk management cycle preparedness, response and recovery. Respondents could make their assessments on a threetiered ordinal scale, ranging from "no relevance", to "low relevance", and "high relevance". In the open-ended questions respondents had the chance to provide further information to substantiate their assessment, for instance by naming/describing specific challenges related to population dynamics in the recovery phase. The answers to the open-ended questions were categorised and coded by using qualitative data analysis. In total, the respondents represent the full range of the disaster risk management cycle: A third of the respondents have an expertise in the field of NHRM (flood protection and torrent control); another other third is affiliated with emergency services (e.g. ambulance services, fire brigades); the remaining third works in spatial planning (17\%) and civil protection (13\%).

To compare the findings of the online survey with developments in Austria's NHRM policy, we conducted a thematic analysis of policy documents and other relevant publications published between 2006 and 2018. We started with a compiled list of national strategies and action plans provided by the Austrian government and then used a snowball approach to add further documents. ${ }^{4}$ We analysed 48 policy documents and other publications in the policy areas of NHRM, spatial and land use planning, and demographic change in general plus the flood risk management plans of all 391 so-called APSFR-regions (regions with a potential significant flood risk) ${ }^{5}$ (for details see Annex 1). This includes strategies and action plans at federal and state level $(n=17)$, brochures of federal ministries and state offices as well as other official publications from both policy fields $(n=29)$ with regard to these topics and selected keywords, such as "demographic", "change", "age", "flood" and "natural hazard". We also included publications from thematically relevant domestic and EU-funded research projects $(n=2)$. The document analysis was based on a thematic analysis (Braun and Clarke 2006), a method for recognising, categorising and analysing topics in the data material. We used the thematic analysis to examine the topic of demographic change in the policy field of NHRM, and conversely, the role of natural hazards in the general field of demographic change. The documents were examined with the aim of formulating relatively broad topics that summarise the content of the material. We used the software programme MAXQDA for a systematic coding and categorisation approach to analyse the large amounts of textual information. The coding combined

\footnotetext{
${ }^{4}$ https://www.frauen-familien-jugend.bka.gv.at/jugend/jugendstrategie/jugendscreening/aktionsplaene-strat egien.html (as of December 2017).

${ }^{5}$ https://www.bmlrt.gv.at/dam/jcr:9a91e5c9-b194-4880-9b62-f73a9fa2c002/APSFR_Liste.pdf; accessed at 9/3/2020.
} 
inductive and deductive approaches of coding. In a first step, the selected keywords were used to assign codes to the respective segments of text in the policy documents. In a second step, the thematically relevant parts of the policy documents were screened in detail for additional text segments using in vivo coding to create new codes. This combined approach guaranteed that no relevant text segments were overlooked in the coding process.

\subsection{Study area description}

Located along the Alpine ridge, Austria is prone to different types of hydro-meteorological hazards (river floods, torrents, debris flows, avalanches). Given its alpine topography, Austria moreover displays significant regional variations related to population distribution and demographic change: Predominately in structurally weak and remote rural areas the impacts of demographic change are already visible.

While many alpine areas in Austria are prone to gravitational hazards (such as landslides, debris flows, avalanches and torrents), fluvial flooding mainly affects the lowerlying parts of the country along Austria's large- and medium-sized rivers. In the past two decades Austria experienced a series of large river floods along the Danube and its tributaries (1997, 2002, 2006, 2013), in the Western Alps (2005) and Southern Alps (2014, 2018), especially the events 2005 and 2018 occurred in rural areas with strong socio-demographic pressures, where a large amount of citizens living in hazard-prone areas as a lack of suitable land. In particular, in the Alpine regions, we observed a strong pressure to build new and more buildings in risk areas, due to lack of permanent settlements.

Concerning socio-demographic change, census data provided by Statistics Austria show that Austria is generally experiencing population growth. Since 1971, Austria's residential population increased by more than $17 \%$ to approximately 8.8 million (2017) and is expected grow to more than 9.6 million by 2050 . However, as fertility rates are well below the natural rate of reproduction (1.52 in 2017), population growth is mainly sustained by international migration. Since 1971 the share of foreign nationals increased from 4.1 to $15.8 \%$ (2018). At the same time, demographic ageing is progressing at a fast rate. By until 2050 the share of older people (65 years and older) is expected to increase to $27.3 \%$ (compared to $15.4 \%$ in 2000), while the share of those younger than 20 years is expected to decrease to $18.8 \%$ (from $23.1 \%$ in 2000). The structure of households is also changing as the trend towards smaller households continues. Since 1984 the average size of households decreased from 2.67 to 2.22 (2017), by 2030 it is expected to further decrease to 2.16 . Accordingly, the combined share of one and two person households has increased from $54.5 \%$ in 1985 to $67.2 \%$ in 2017 (scenario 2030: 70.2\%). Moreover, the number of people with secondary residences has increased considerably in recent years, from approximately 850000 (2001) to over 1.2 million in 2016. The increase of secondary homes can be observed in tourism hot spot regions like Tyrol, Salzburg or Carinthia as well as in rural regions like Lower Austria and Burgenland. The strong focus on the tourism regions is mainly defined by the attraction of leisure activities in the mountains or close to the lakes, which also increases the number of new immigration (so-called amenity migration) from outside the country (Bender and Kanitscheider 2012). The increase in Lower Austria and Burgenland is mainly based on the proximity to the City of Vienna. Analysing the citizenship, we observe that most of the second-home residents have an Austrian citizenship or arrive from other European countries, such as Germany or the Netherlands (Wisbauer et al. 2013). Finally, Austria's working population is increasingly mobile: While in 1971 only 

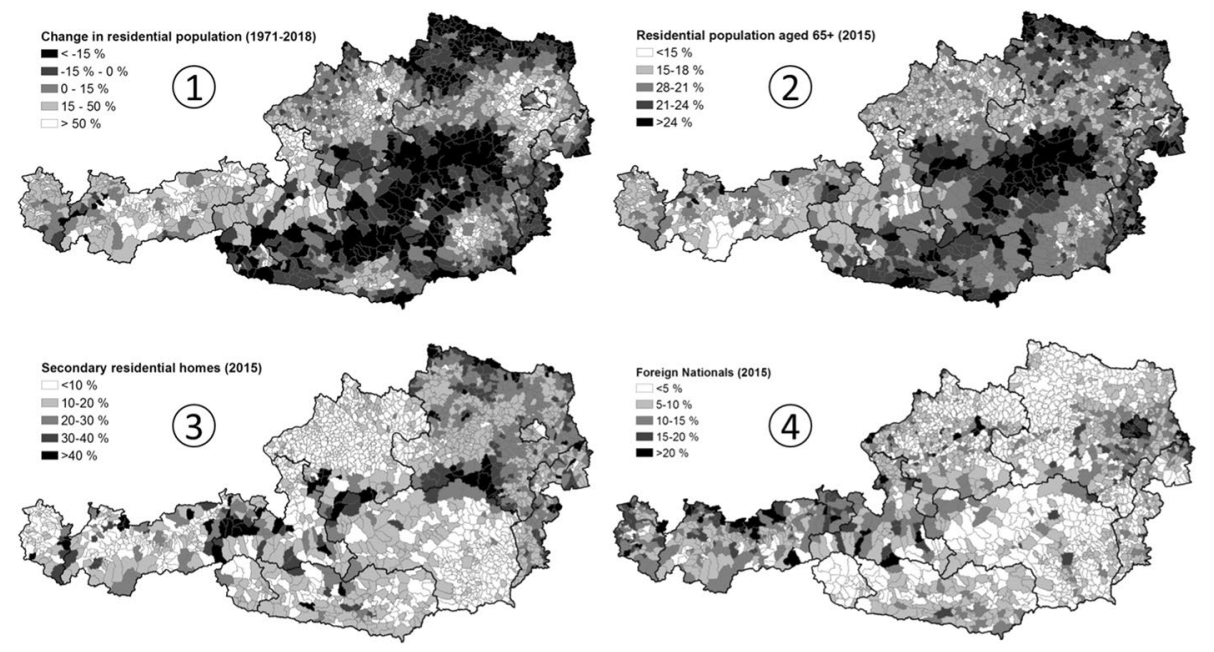

Fig. 1 Overview maps of Austria: (1) population change, 1971-2018 (Statistik Austria 2018); (2) share of people aged 65 years and older (Statistik Austria 2015); (3) share of secondary homes (Statistik Austria 2015); (4) share of foreign nationals (Statistik Austria 2015)

about one in four people commuted to work outside their municipality of residence, their share has more than doubled to $52.9 \%$ (2016).

Figure 1 (maps 1-4), illustrating the regions that face demographic ageing, population decline and other dimensions of socio-demographic change, shows that these demographic developments are not uniformly distributed across the territory of Austria:

- Map 1 shows: Population growth mainly takes place in Austria's urban agglomerations (such as the Vienna metropolitan region) and in the western parts of the country. Peripheral border-regions in the North- and Southeast parts of Austria (along the former Iron Curtain) as well as post-industrial and remote inner-alpine regions stagnate or are experiencing population decline owing to low inmigration and high outmigration rates.

- Map 2 shows: Regions affected by population loss also have a higher share of older people, as predominately young adults migrate to the urban centres i.a. for higher education or for high-skilled jobs; on the other hand, the median age increases in these areas as many older people (at least temporarily) move to rural areas during retirement.

- Map 3 shows: International migration is mainly targeted towards the (peri)urban regions, tourist regions (in the Western provinces) as well as manufacturing regions. Consequently, these areas have a significantly higher share of foreign nationals than remote rural areas.

- Map 4 shows: Many areas affected by outmigration and ageing also have a higher share of second-homes, as real estate values are low and vacancy rates are high. Tourist regions in alpine areas are also attractive for second-home residents. By contrast, these regions are characterised by high real estate prices and a shortage of (affordable) housing.

The comparison of Fig. 1 (maps 1-4) with Fig. 2 shows that many regions facing demographic ageing, population decline and/or other dimensions of socio-demographic change 


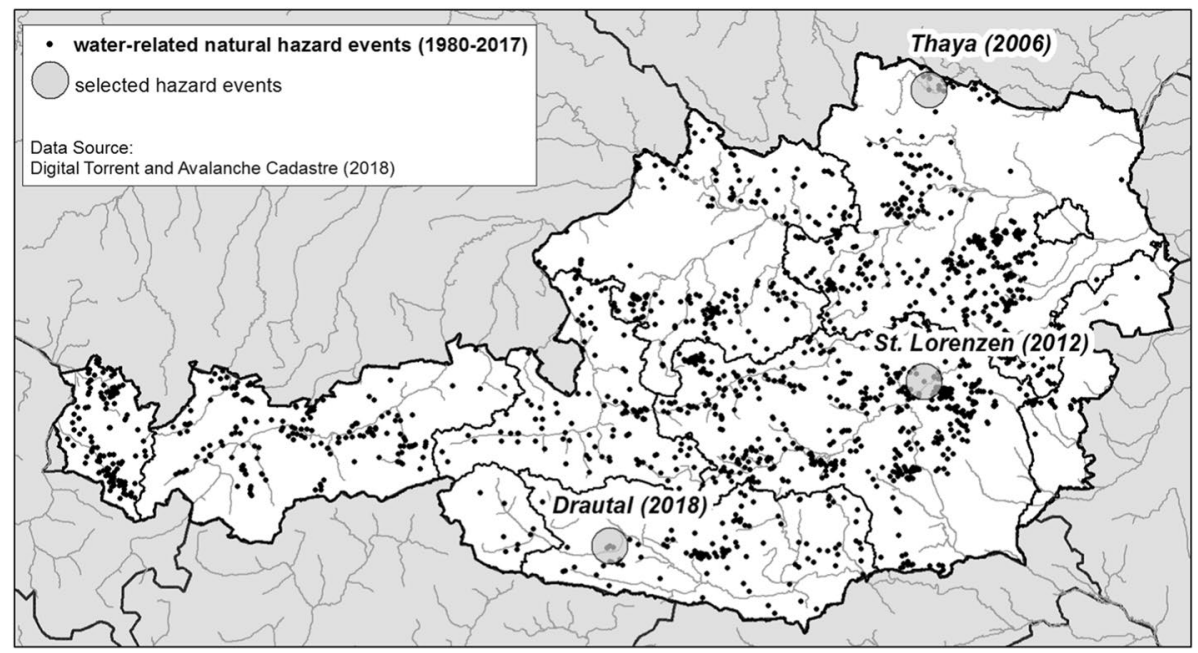

Fig. 2 Water-related natural hazard events, 1980-2017 (WLV 2018)

are also prone to hydro-meteorological hazards. Between 1980 and 2018 over 2200 damaging events have been recorded across the country, many in regions affected by demographic change.

\section{Results}

In this section we present the empirical findings concerning the interlinkages between population dynamics and NHRM in Austria. We first summarise the main results from the online survey and then outline the linkages according to the thematic document analysis.

\subsection{Online survey: insights from Austria's NHRM community}

Results from the online survey indicate that population dynamics are currently not considered in Austria's NHRM (policies). Specifically, only about $8 \%$ of the respondents consider demographic ageing to be of strong relevance in today's NHRM. This evaluation is similarly low for the other dimensions (see Fig. 3). These results stand in stark contrast to the assessment of their expected future relevance: Survey respondents in particular consider ageing (51\%), population change (47\%) and changing household structures $(42 \%)$ to be strongly relevant factors in future NHRM, while the significance of immigration and pluralisation $(19 \%)$ is considered to be significantly lower.

\subsubsection{Demographic ageing}

The survey results confirm that demographic ageing plays an important role at different stages of the disaster risk management cycle (see Fig. 4). Specifically, ageing is considered to influence the individual and collective capacities to cope with and respond to extreme events. For one, respondents highlight that an ageing population has "limited physical 


\section{Current consideration and future relevance of different constituents of demographic change in Austria's natural hazard risk management ( $n=53$ )}

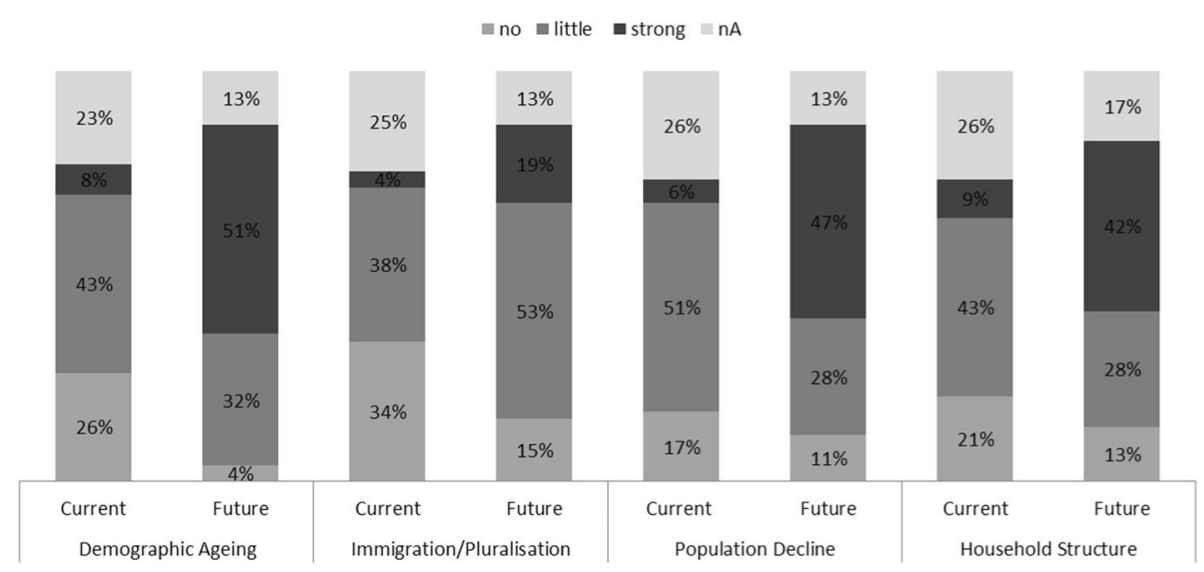

Fig. 3 Comparison between the survey respondents' evaluation of the current consideration of the demographic constituents and their expected future relevance in Austria's NHRM

capabilities"6 (mobility, physical fitness, etc.) and thus "impaired capacities for self-help". As a particularly vulnerable population group, older people are seen to be more reliant on emergency forces, which in turn face the challenge to better account for the "specific needs" of this population group. In this regard, respondents for instance highlight that older people in need of care require specific assistance during evacuation.

Secondly, the survey respondents point out that the emergency forces themselves are also affected by demographic ageing. With increasing age, first responders have "less stamina" to conduct the physically and mentally challenging rescue operations. Importantly, demographic ageing also "reduces the operational capacities" of rescue organisations because there is a smaller pool of young adults and it is becoming "increasingly difficult to recruit emergency personnel". Demographic change, however, not only plays a significant role in terms of capacities for immediate response-an ageing society also faces the challenge of reduced "manpower", which plays a crucial role for the recovery phase, when there is a need to rebuild and recondition damaged buildings and infrastructure.

\subsubsection{Population decline}

Survey participants generally consider that population decline has less of an influence on NHRM than demographic ageing. Nevertheless, on average about one in three respondents attest that population decline due to long-term demographic trends, such as low fertility rates or selective rural outmigration, is a "strongly relevant" factor for risk management (see Fig. 4). In contrast to ageing, population decline is considered to play a significant role with regard to hazard and risk prevention. Respondents highlight that even in regions facing population decline "land development in hazard areas poses a significant problem" due to the large supply of building land in flood-prone areas. In this regard, some respondents,

\footnotetext{
${ }^{6}$ Direct quotes from the survey respondents are translated from German into English.
} 
Relevance of demographic ageing in the different phases of hazard risk management $(n=53)$

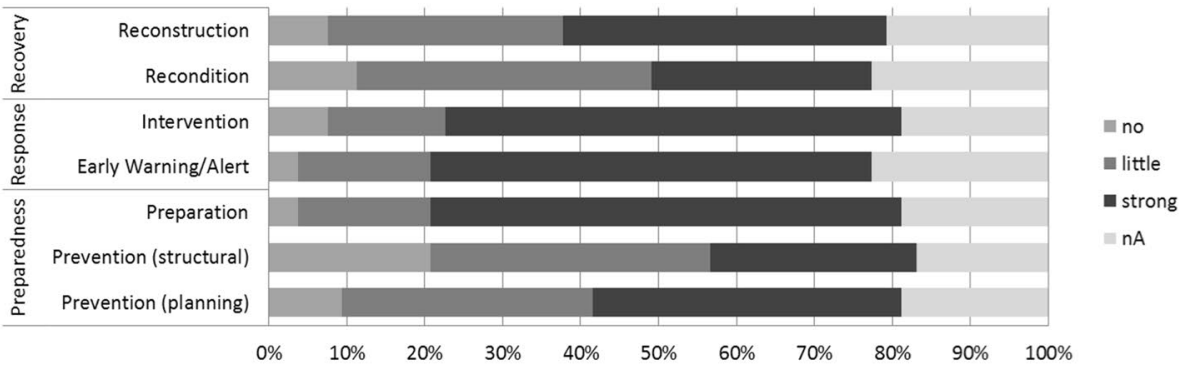

Relevance of population decline in the different phases of hazard risk management $(n=53)$

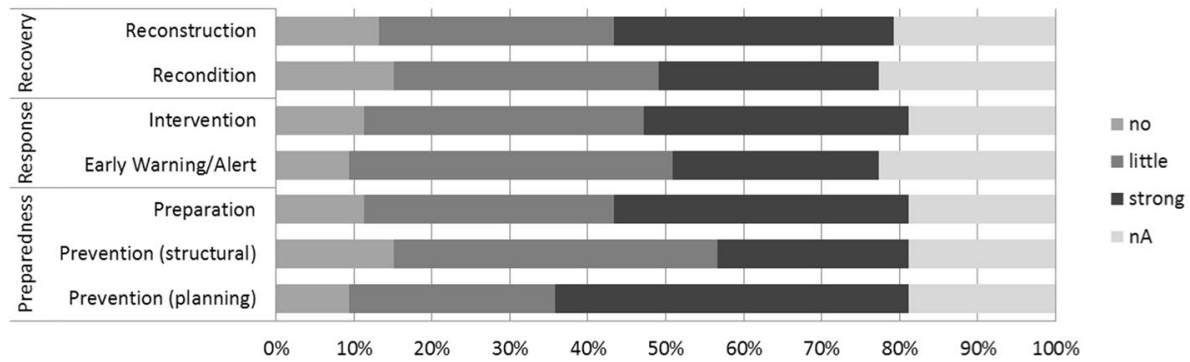

Relevance of changing household structures in the different phases of hazard risk management $(n=53)$

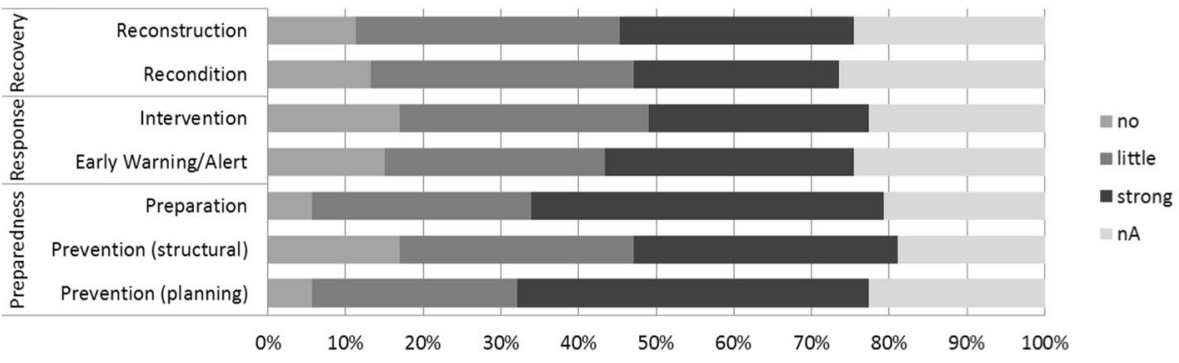

Relevance of immigration and pluralisation in the different phases of hazard risk management $(n=53)$

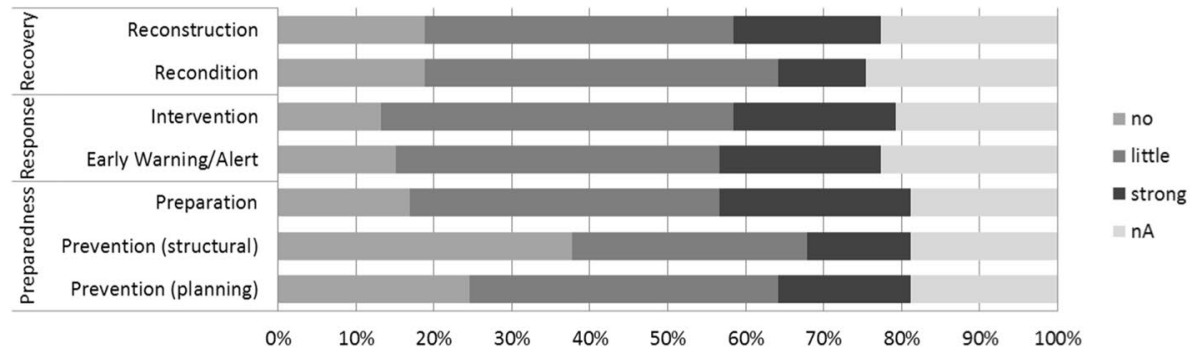

Fig. 4 Survey respondents' evaluation concerning the relevance of (i) demographic ageing, (ii) population decline, (iii) changing household structure and (iv) immigration and pluralisation across the different stages of the disaster risk management cycle 
however, also see population decline as "an opportunity" because "non-developed building land may be rezoned more easily into open land given the decreasing demand for building land".

Similarly, survey participants point out that a decreasing number of people living in protected areas imply a "diminishing efficiency of [structural] prevention measures". Especially smaller municipalities with a declining residential population face the challenge to cover the "high construction and maintenance costs" of technical defence measures. Population decline thus ultimately raises the question "why defence measures shall be maintained in areas where there is no need for protection". In the case of damage to flood defences, there may also arise the need to consider different options of responding to a "demographically changing society", above all whether "to withdraw from affected areas or to reconstruct [protection infrastructure]". Against this background, for some respondents population decline may actually open up possibilities "to refrain from adopting structuraltechnical measures" and "provide more room for nature in remote regions", for instance by fostering non-technical and nature-based solutions in NHRM.

Moreover, with regard to the phases response and recovery, survey respondents highlight that population decline (akin to demographic ageing) significantly "influences the available personnel structure and recruiting basis for voluntary organisations". Since population decline in Austria's remote regions is largely determined by the outmigration of young adults, it "may be increasingly difficult for emergency relief organisations to have sufficient volunteers at their disposal". In reference to the concept to "build back better", respondents also see the challenge to adapt existing organisational structures to the changing needs of affected population groups. In this way, "not only an improvement in resilience, but also an improvement in the basic function of the infrastructure can be achieved in reconstruction".

\subsubsection{Changes in household structure}

Changes in the household structure are also considered to influence NHRM in multiple ways. For one, the general trend towards smaller households and the increase in land consumption per capita poses a serious challenge for planning-related measures of hazard prevention (see Fig. 4), because land development is one of the underlying factors for the increase in damage potential in hazard areas. Moreover, the increasing share in oneperson households influences the readiness for preparation and response. As fewer people are embedded in inter-generational family structures, the capacities for "inner-family selfhelp diminish". In this regard the survey respondents expect that "individual initiatives will decline" and that people will increasingly rely on "external help", a phenomenon that is also described as the "institutionalisation" of NHRM, in particular in relation to hazard response and recovery.

Secondly, survey respondents confirm that socio-economic changes result in an increasing number of people commuting on a daily basis. This also applies to the (voluntary) emergency services. As many volunteers work in urban areas and are thus often "not able to participate in rescue operations during work hours, [these organisations] have difficulties providing operational emergency personnel on weekdays".

Finally, second-home ownership is considered to pose a challenge for NHRM. When damages to buildings occur (e.g. flooded cellars) or if the need for evacuation arises in extreme events, it is difficult for rescue services to determine, "whether a second-home is currently inhabited or occupied". Survey respondents also highlight that second-home 
owners may not be available to support communal reconstruction efforts, as they "are busy taking care of their primary residence". In terms of flood insurance, there are no differences between second-home owners and main residences in taking flood insurance. In general, there is a low rate of insurance penetration in Austria as the impacts of natural hazards are mostly compensated by the public catastrophe fund (Katastrophenfonds) (Hanger et al. 2018). However, second-home residents are excluded from the public catastrophe fund as the public administration assumes that they have enough financial savings and not the vital need to be compensated for the damages.

\subsubsection{Immigration and pluralisation}

Finally, immigration and pluralisation are considered to be by far the least relevant demographic constituent across all phases of NHRM. Nevertheless, in particular with regard to preparation, early warning and alert plans, the survey respondents see the need to adapt to the changing socio-cultural conditions (Fig. 4). In particular, survey results show that it is becoming necessary to "adapt alarm plans" in consideration of different cultural "understandings of risk" and to ensure "multilingual communication" with affected persons who do not understand emergency instructions in German.

\subsection{Thematic analysis of policy documents}

Currently, Austria has no overarching national strategy or action plan regarding the issue demographic change as such. However, there are various national strategies and action plans in other policy fields. Some of these action plans and strategies relate directly or indirectly to demographic change strategies, and some of them deal with specific aspects or consequences of demographic change. This fits with the scientific state-of-the-art that criticises that ongoing discussions about demographic change focus on pensions, health care and care for older people, whereas other challenges are widely ignored (Schipfer 2005; Báchora et al. 2016). Accordingly, our knowledge about the phenomenon of demographic change, its main causes, its spatial and temporal manifestations and its consequences is fragmentary and incomplete (Hiess et al. 2017).

The thematic analysis of main topics and problem perceptions in the two policy fields "demographic change" and "natural hazard management" shows quite clearly a significant lack of overlapping content. If demographic change is addressed at all, it is associated with policy areas such as labour and housing market policies, health and care, finance, education, mobility and infrastructure planning. We did not find any connection of demographyrelated discussions with NHRM. One potential link between the two policy fields is the issue of volunteering, which is directly addressed for instance in the so-called Master Plan for Rural Areas (BMLFUW 2017) in connection with disaster relief: "[a]lmost half of Austrians aged 15 or over are volunteers. This voluntary commitment characterizes rural areas and ensures essential services in the area of disaster relief" (ibid: 77). Upholding this level of voluntary engagement is also an important goal for NHRM because it might also have a positive effect on the available personnel capacities in the preparedness and response phase.

If we look at the other side of the same coin, namely policy documents in the policy area of NHRM, demographic change is similarly underrepresented. Most documents at the federal and state level do not address demographic change at all. The issue is only discussed as a new challenge in the subdomain of disaster management with regard to emergency response. Also 
here the focus is on the commitment of volunteers. For instance, the strategy of the National Crisis and Disaster Management (SKKM) entitled "SKKM Strategy 2020" (BMI 2009a) repeatedly emphasises the central role of (voluntary) disaster risk organisations: "Maintaining the volunteer involvement in civil protection is a key strategic issue for maintaining the quality of the entire existing system and therefore a matter of overriding importance. Rescue and fire brigade services represent the resource pool and thus also the recruitment area for young volunteers" (ibid: 17; own translation). Also the sub-report "Disaster Management" of an encompassing evaluation programme (FLOODRISK Evaluation) provides a similar argument (Jachs and Kreuzer 2015): Accordingly, due to social developments, demographic changes and outmigration, it is already necessary today to take measures to increase the motivation for volunteering. It emphasises that many volunteer organisations face the challenge of attracting enough new members. Especially volunteers aged 20-40 years are often hardly available due to professional and private obligations as well as more attractive possibilities of leisure time activities (ibid: 31). In addition, in the Ministry of the Interior's magazine Public Safety we found articles dealing with problems in the case of an evacuation particularly related to older people (cf. Jachs 2014, 2015) or with differences in the reactions of various population groups to information offers and warnings in the event of a disaster (cf. Jachs 2011).

The National Flood Risk Management Plan (BMLFUW 2015) addresses demographic change only indirectly, although there would be several opportunities for more direct links, for instance in the fields of action entitled "Awareness raising" and "Preparation". When it comes to information and raising risk awareness as part of preparedness, the Federal Ministry deliberately focuses on "targeting young people (13-19 years)" (ibid: 127). Furthermore, the Ministry assumes that "the widespread voluntary participation in the disaster risk organizations" (ibid: 142) will continue in the future, which is at least questionable in regions with population decline, where recruiting young members for these organisations might become a problem.

A major contribution to awareness raising has been made in recent years by thematically focused research projects, such as the ACRP-funded project VOICE, which developed measures for the long-term engagement of voluntary work in civil protection (Balas and Glas 2015) or the EU-funded project PrepAGE, which focused on improving disaster risk management for older people in the EU (Strümpel et al. 2016).

In summary, the challenges of demographic change for natural hazard management in Austria are addressed in scientific projects and in some public articles, but hardly in any policy documents. Currently, interlinkages between demographic dynamics and NHRM are reflected primarily by key organisations in the field of disaster management, such as rescue organisations which are directly affected by changes in the age structure both in the recruitment of volunteers and in the special needs of older people in cases of emergency.

Accordingly, the thematic analysis points to three issues in the phases of preparedness and response that could potentially strengthen the interlinkages between the two policy fields in the future. The first one is the issue of voluntary commitment to emergency and rescue organisations, the second issue refers to the specific needs of older people during rescue operations, and the third issue is information and education, especially special needs of older people concerning the accessibility and comprehensibility of risk communication. 


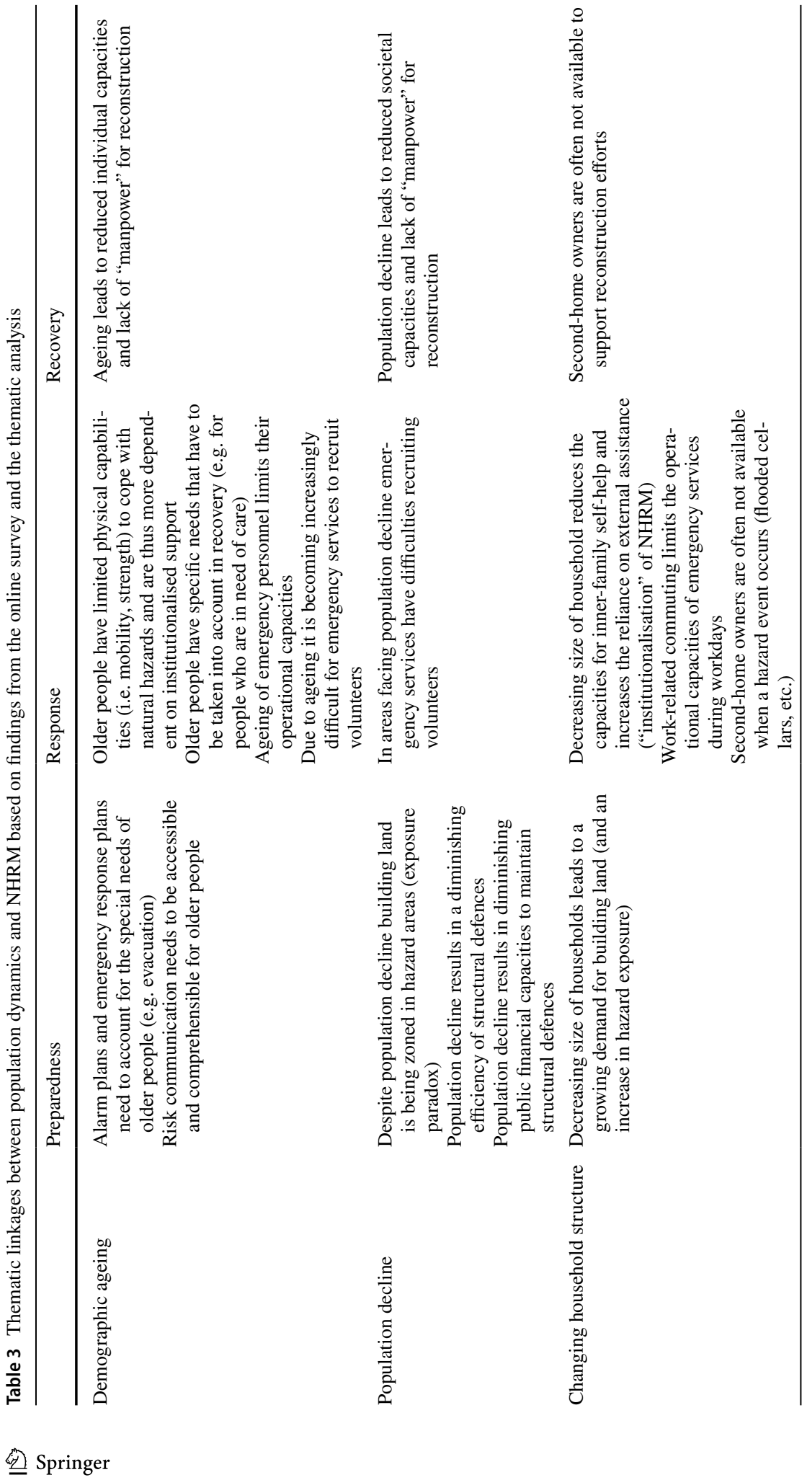




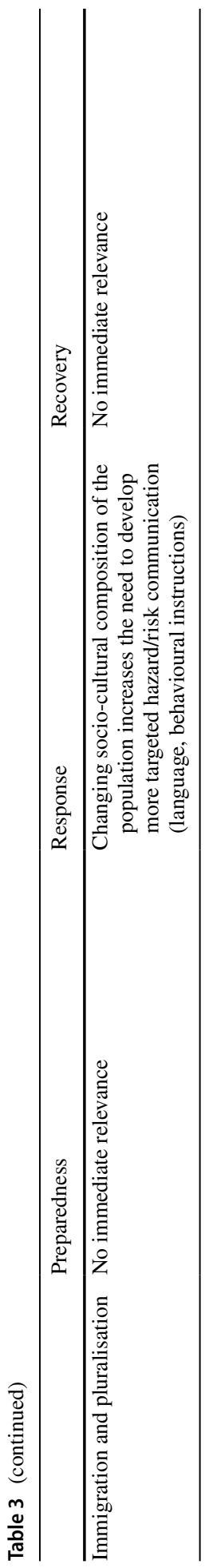




\section{Discussion}

Our empirical analysis of NHRM policy and implementation in Austria shows that population dynamics and consequent changes are pressing policy issues that are currently not addressed. Table 3 summarises their relevance across the different phases of the disaster risk management cycle.

First of all, issues the Austrian NHRM community is relatively well aware of are the preparedness-phase are the specific needs of older people, and potential impacts of population decline onto NHRM. The question of (fewer) resident children in households at risk as well as migration does not appear as a major issues - in contrast to more or less recently published scholarly literature (e.g. Basolo et al. 2017; Cutter and Finch 2008).

Concerning the response phase, the overlaps between the findings from our online survey and experiences from international research are considerably larger. Compared to what we found in the literature, the participants of our survey expressed almost identical concerns regarding the capabilities of older people and the associated consequences for communities' response capacities (e.g. Tragaki et al. 2018, 11), the lack of on-site presence of residents (e.g. Lee 2014, 34) as well as immigration and pluralisation (e.g. Ahsan et al. 2016). Beyond that, the NHRM actors pointed further issues, such as consequences of an ageing community for the recruiting of voluntary organisations.

Recovery is the phase both NHRM actors and scholars seem to pay the least attention to. They identify challenges that result from a lack of people who are directly involved in reconstruction efforts (e.g. because second-home owners lack attachment to the community; Cheong 2018, 8), but do not mention immigration and pluralisation as a pressing issue. The major difference between the policy community and scholars concerns demographic ageing: Whereas the first emphasises a lack of "manpower" for reconstruction, the latter are rather focusing on individual consequences for older people (e.g. Bolin and Kurtz 2018, 259).

Finally, the general paucity of publications that actually take into account dynamic dimensions of demographic change, such as population decline and ageing (e.g. McGee and Russell 2003; Chakraborty et al. 2005; McLennan and Birch 2005; Cutter and Finch 2008; Fekete 2009a; Roth et al. 2014; Dressler et al. 2016; Fekete et al. 2016) suggests that current NHRM lacks future-oriented approaches, which might also be of interest to the Austrian NHRM community.

Probably the main innovation of this study lies in its conceptual framework, which helps to reveal and frame a comprehensive range of thematic interrelations between population dynamics and NHRM. By applying a broader and more dynamic understanding of population change, we consider a range of socio-demographic developments and dissect their interrelations across the full range of the disaster risk management cycle. Thus, this conceptual approach deepens our understanding of social developments and their determining effects on risk management policies.

While the conceptual framework provided suitable guidance for our empirical analysis by allowing us to disentangle the broad range of challenges for NHRM connected to sociodemographic change, we also identified weaknesses that must be addressed. The online survey, which we structured according to the framework's analytical categories, showed that (i) the framework itself is rather complex and consists of too many sub-categories, and (ii) it is difficult to clearly separate the different phases of the risk management cycle, 
which becomes particularly evident by the large thematic overlaps between the phases response and recovery.

Overall, the combination of the online survey with the thematic document analysis allows to capture policy perspectives from the NHRM policy community. With its long tradition in the management of hydro-meteorological hazards, Austria generally presents a good case for such an analysis. It shows that the issue of population dynamics and demographic change is widely disregarded in the respective policy documents. This might be directly connected to the fact that many actors, especially those involved in the technical and planning side of hazard prevention, lack experience in engaging with this issue. This comes somehow as a surprise, given the surprisingly clear message from actors in emergency response highlighting that socio-demographic change is a "real" challenge that already affects the operational capacities in Austria's disaster risk management and demanding more concerted action across the NHRM policy community.

\section{Conclusions}

The most prominent gap appeared between the findings of our online survey, which pointed to a number of highly relevant interrelations between demographic change and NHRM that are also present in scholarly literature, and the results of the analysis of Austria's policy documents, which revealed only very few thematic overlaps between the two thematic areas. This gap between the assessment of the Austrian NHRM community and actual policies emphasises the strong relevance of our study and points the way for necessary adaptations of Austria's NHRM alike. Obviously, there is great demand for political developments to catch up with already occurring and soon to be expected developments. Consequently, three major findings can be summarised: (i) Policy makers across different sectors acknowledge the growing relevance of demographic change for NHRM. (ii) Emergency services and other actors involved in hazard response and recovery already face the adverse consequences of demographic change, such as the growing number of older people demanding specific assistance or the lack of work force due to ageing, outmigration or work-related commuting. (iii) Policy documents of Austrian NHRM policy fail to reflect both current and expected demographic changes.

Both our broad engagement with the literature and the application of our conceptual framework to our case study provide strong evidence for the relevance of demographic change for NHRM. Despite multiple indications and references that demographic change is a pressing issue in practice, and will be even more so in the future, there is considerable lack of attention in current planning and policy making.

In overall, we observe two main limitations of the study. First, the selected online survey sample might be biased from respondent self-selection as blue light organisations are overrepresented. In a larger sample, we would expect even lower importance of the role of socio-demographic change in NHRM. Second, further case studies (especially outside of Austria and Europe) would help to address these limitations, could expand the framework for the role of socio-demographic change in NHRM and could illustrate the actual political strategies and outcomes of socio-demographic change to local and regional risk management. 
In fact, the review of the scientific state-of-the-art shows that also in theory there is still a lack of analytical depth regarding medium- to long-term demographic developments and their consideration in NHRM. Despite a large body of literature addressing individual demographic constituents, only a few publications actually take into account the dynamic dimensions of demographic change (Clar 2019). Although based on only one singular case study, this paper demonstrates the importance of applying a dynamic perspective onto socio-demographic change and its relevance for NHRM. In this regard, scholars can benefit in two particular ways from our overarching perspective: For one, the analysis shows that current knowledge about thematic interrelations between demographic factors and NHRM is fragmented and that there are multiple aspects of population dynamics that should be explored in greater depth and with a clear focus on long-term developments. Second, this study highlights the importance of considering regional differences, in order to develop a clear understanding of particular challenges in NHRM. This applies in particular to differences between remote rural areas and urban areas. Recently, especially the focus on the first has been neglected. ${ }^{7}$

On the practical side, our analysis has confirmed the first impression that, according to major policy documents, NHRM in Austria lacks consideration of demographic change. As other spheres of Austrian policy do consider population dynamics, future studies would do well to examine policy-making dynamics of this particular policy area. The fact that thematic connections are evident (such as the development of the voluntary sector) and that practitioners already experience consequences of demographic ageing, population decline and changing household structure emphasises this call for further examinations. In addition, it highlights the need for future-oriented NHRM (policy), which strategically takes into account socio-demographic change, considers them in long-range planning decisions and adapts organisational structures accordingly.

Funding Open access funding provided by University of Natural Resources and Life Sciences Vienna (BOKU). The research project Demographic Change and Hydrological Hazards: Flood Risk Management in Alpine Areas Facing Population Decline and Demographic Ageing (DemoHazAlps) that led to this paper was funded by the Austrian Academy of Sciences (ÖAW) within the research programme Earth System Sciences (ESS).

Open Access This article is licensed under a Creative Commons Attribution 4.0 International License, which permits use, sharing, adaptation, distribution and reproduction in any medium or format, as long as you give appropriate credit to the original author(s) and the source, provide a link to the Creative Commons licence, and indicate if changes were made. The images or other third party material in this article are included in the article's Creative Commons licence, unless indicated otherwise in a credit line to the material. If material is not included in the article's Creative Commons licence and your intended use is not permitted by statutory regulation or exceeds the permitted use, you will need to obtain permission directly from the copyright holder. To view a copy of this licence, visit http://creativecommons.org/licenses/by/4.0/.

\section{Appendix}

See Table 4.

\footnotetext{
${ }^{7}$ How important it is to focus on these particularities can be seen in this report (which is one of the exceptions from this lack of attention; note) about disaster preparedness of the most vulnerable residents of three largely rural counties in California: https://www.auditor.ca.gov/pdfs/reports/2019-103.pdf; accessed at 2/21/2020.
} 
Table 4 National strategies and action plans, policy documents and other publications used in the thematic analysis

Government programmes

National strategies and action plans

Policy documents in the field of NHRM, in particular flood risk management

Policy documents in the field of spatial planning

Policy documents in the field of disaster management/civil protection

Policy documents in the field of demographic change
Arbeitsprogramm der österreichischen Bundesregierung 2013-2018 (BKA 2013); Regierungsprogramm 2017-2022 (BKA 2017a); Nationales Reformprogramm Österreich (BKA 2017b)

Energiestrategie Österreich (BMWFJ 2010); Nationaler Aktionsplan Behinderung 2012-2020 (BMASK 2015); Koordinierte FTI-Strategien und -Maßnahmen für Mobilität und Lebensqualität vor dem Hintergrund des demografischen Wandels (BMVIT et al. 2015); Masterplan für den ländlichen Raum (BMLFUW 2017a); Die österreichische Strategie zur Anpassung an den Klimawandel, Teil 1 - Kontext (BMLFUW 2017b); Die österreichische Strategie zur Anpassung an den Klimawandel, Teil 2 - Aktionsplan (BMLFUW 2017c); mission 2030. Die österreichische Klima- und Energiestrategie (BMNT 2018)

Hochwasserschutz in Österreich (BMLFUW 2006); Anpassungsstrategien an den Klimawandel für Österreichs Wasserwirtschaft (BMLFUW 2011a); Vorläufige Bewertung des Hochwasserrisikos 2011 (BMLFUW 2011b); Schutz. Wirkung. Lebensraum: Die Wildbachund Lawinenverbauung (BMLFUW 2014); Nationaler Hochwasserrisikomanagementplan (BMLFUW 2016a); APSFR Hochwasserrisikomanagementpläne (in total 391) (BMLFUW 2016b); Technische Richtlinien der Bundeswasserbauverwaltung (RIWA-T) (BMLFUW 2016c); FloodRisk-Evaluation Synthesebericht (BMLFUW 2015); Klimawandel in der Wasserwirtschaft (BMLFUW 2017d)

Programm zur hochwassersicheren Entwicklung der Siedlungsräume (Amt der Steiermärkischen Landesregierung 2008); Hochwasserschutz im Burgenland (Amt der Burgenländischen Landesregierung 2009); Aktionsprogramm Hochwasserschutz 2018 (Land Salzburg 2013); Hochwasser 2013-Analysen, Schlussfolgerungen, Maßnahmen (Amt der niederösterreichischen Landesregierung 2014); Hochwasserrisikomanagementpläne Steiermark (Amt der Steiermärkischen Landesregierung 2016); Wasserwirtschaftsstrategie 2020 des Landes Vorarlberg (Amt der Vorarlberger Landesregierung 2016); Der Schutzwasserwirtschaftliche Raumentwicklungsplan SREP (Amt der Kärntner Landesregierung 2017);

ÖROK-Empfehlung Nr. 20: Empfehlungen zur besseren Berücksichtigung von Naturgefahren in der Raumplanung (ÖROK 1986); ÖROKEmpfehlung Nr. 52 zum präventiven Umgang mit Naturgefahren in der Raumordnung (Schwerpunkt Hochwasser) (ÖROK 2005); ÖROKEmpfehlung Nr. 54: Risikomanagement für gravitative Naturgefahren in der Raumplanung (ÖROK 2015); ÖROK-Empfehlung Nr. 57 zum Hochwasserrisikomanagement (ÖROK 2017); Österreichisches Raumentwicklungskonzept ÖREK 2011 (ÖROK 2011); Österreichische Regionen mit Bevölkerungsrückgang: Analysen und Handlungsempfehlungen (Hiess et al. 2017); Demographischer Wandel in den Alpen (Ständiges Sekretariat der Alpenkonvention 2015)

Staatliches Krisen- und Katastrophenschutzmanagement: Rechtliche und organisatorische Grundlagen (BMI 2013); SKKM-Strategie 2020 (BMI 2009b); Krisen- und Katastrophenschutzmanagement in Niederösterreich (Amt der NÖ Landesregierung, 2009)

The research project Demographic Change and Hydrological Hazards: Flood Risk Management in Alpine Areas Facing Population Decline and Demographic Ageing (DemoHazAlps) that led to this paper was funded by the Austrian Academy of Sciences (ÖAW) within the research programme Earth System Sciences (ESS).

Herausforderung Demografie: Den gesellschaftlichen Wandel zukunftsfähig gestalten (BMLFUW 2009) 
Table 4 (continued)

\begin{tabular}{|c|c|}
\hline $\begin{array}{l}\text { Articles in "Öffentliche Sicher- } \\
\text { heit", magazine of the Federal } \\
\text { Ministry of the Interior }\end{array}$ & $\begin{array}{l}\text { Aus dem Inneren. Staatliches Krisen- und Katastrophenschutzmanage- } \\
\text { ment (Jachs 2011a); Unterschiedliche Reaktionen. Die Bedeutung } \\
\text { sozialer Faktoren für die Warnung im Katastrophenfall (Jachs 2011b); } \\
\text { Ausnahmezustand Massenevakuierung (Jachs 2014a); Nationale } \\
\text { Risikoanalyse (Jachs 2014b); Besondere Bedürfnisse (Jachs 2015a); } \\
\text { Neue Herausforderungen (Jachs 2015b); Katastrophenschutz in Öster- } \\
\text { reich (Jachs and Stocker 2015); Wildbäche und Lawinen (BMI 2015); } \\
\text { Understanding Risk Austria (BMI 2016) }\end{array}$ \\
\hline Scientific projects & $\begin{array}{l}\text { Freiwilligenengagement in der Zukunft (Balas and Glas 2015) (VOICE } \\
\text { project); Enhancing disaster management preparedness for the older } \\
\text { population in the EU. National Workshop - Report (Kiener 2015) } \\
\text { (PrepAGE project) }\end{array}$ \\
\hline
\end{tabular}

\section{References}

Adeola FO (2009) Katrina cataclysm: does duration of residency and prior experience affect impacts, evacuation, and adaptation behavior among survivors? Environ Behav 41(4):459-489. https://doi. org/10.1177/0013916508316651

Adger WN (2000) Social and ecological resilience: are they related? Prog Hum Geogr 24(3):347-364. https ://doi.org/10.1191/030913200701540465

Ahsan MN, Takeuchi K, Vink K, Warner J (2016) Factors affecting the evacuation decisions of coastal households during Cyclone Aila in Bangladesh. Environ Hazards 15(1):16-42. https://doi. org/10.1080/17477891.2015.1114912

Aldrich DP (2011) The power of people: social capital's role in recovery from the 1995 Kobe earthquake. Nat Hazards 56(3):595-611. https://doi.org/10.1007/s11069-010-9577-7

Allen CR, Fontaine JJ, Pope KL, Garmestani AS (2011) Adaptive management for a turbulent future. J Environ Manag 92(5):1339-1345. https://doi.org/10.1016/j.jenvman.2010.11.019

Amt der Burgenländischen Landesregierung (2009) Hochwasserschutz im Burgenland. Eisenstadt

Amt der Kärntner Landesregierung (2017) Der Schutzwasserwirtschaftliche Raumentwicklungsplan SREP. Klagenfurt

Amt der niederösterreichischen Landesregierung (2009) Krisen- und Katastrophenschutzmanagement in Niederösterreich. Sankt Pölten.

Amt der niederösterreichischen Landesregierung (2014) Hochwasser 2013 - Analysen, Schlussfolgerungen, Maßnahmen. Sankt Pölten

Amt der Steiermärkischen Landesregierung (2008) Programm zur hochwassersicheren Entwicklung der Siedlungsräume. Graz

Amt der Steiermärkischen Landesregierung (2016) Hochwasserrisikomanagementpläne Steiermark. Graz

Amt der Vorarlberger Landesregierung (2016) Wasserwirtschaftsstrategie 2020 des Landes Vorarlberg. Bregenz

Amundsen H (2012) Illusions of resilience? An analysis of community responses to change in northern Norway. Ecol Soc. https://doi.org/10.5751/ES-05142-170446

Armas I, Ionescu R, Posner CN (2015) Flood risk perception along the Lower Danube river, Romania. Nat Hazards 79(3):1913-1931. https://doi.org/10.1007/s11069-015-1939-8

Aubrecht C, Fuchs S, Neuhold C (2013) Spatio-temporal aspects and dimensions in integrated disaster risk management. Nat Hazards 68(3):1205-1216. https://doi.org/10.1007/s11069-013-0619-9

Statistik Austria (ed) (2015) Abgestimmte Erwerbsstatistik und Arbeitsstättenzählung. Wien

Statistik Austria (ed) (2018) Statistik des Bevölkerungsstandes. Wien

BABS (2014) Integrated risk management. Its importance in protecting people and their livelihoods. Federal Office for Civil Protection, Berne

Báchora, R., Leitner, K., Steinheimer, E. (2016). Herausforderungen des demographischen Wandels - Strategien und Konzepte der Politik und Wirtschaft. Österreich im Ländervergleich mit Deutschland, Großbritannien und Schweden. Wien: Center für Strategische Analysen

Balas M, Glas N (2015) Freiwilligenengagement in der Zukunft. Maßnahmen für die langfristige Absicherung der Freiwilligenarbeit im Katastrophenschutz. Umweltbundesamt, Wien 
Barnett J, Adger WN (2018) Mobile worlds: choice at the intersection of demographic and environmental change. Annu Rev Environ Resour 43(1):245-265. https://doi.org/10.1146/annurev-environ-10201 6-060952

Barsky L, Trainor J, Torres M (2006) Disaster realities in the aftermath of Hurricane Katrina: revisiting the looting myth. Miscellaneous report \#53, Natural Hazards Center quick response report number 184

Basolo V, Steinberg LJ, Gant S (2017) Hurricane threat in Florida: examining household perceptions, beliefs, and actions. Environ Hazards 16(3):253-275. https://doi.org/10.1080/17477891.2016.12779 68

Becker P (2011) Whose risks? Gender and the ranking of hazards. Disaster Prev Manag Int J 20(4):423433. https://doi.org/10.1108/09653561111161743

Bender O, Kanitscheider S (2012) New immigration into the European Alps: emerging research issues. Mt Res Dev 32(2):235-241. https://doi.org/10.1659/MRD-JOURNAL-D-12-00030.1

Berg K, Wilson B (2013) A multilevel analysis of private-vehicle evacuation clearance times along the US Gulf coast. Environ Hazards 12(3-4):291-310. https://doi.org/10.1080/17477891.2013.837024

Bian R, Wilmot CG (2017) Measuring the vulnerability of disadvantaged populations during hurricane evacuation. Nat Hazards 85(2):691-707. https://doi.org/10.1007/s11069-016-2598-0

Bihari M, Ryan R (2012) Influence of social capital on community preparedness for wildfires. Landsc Urban Plan 106(3):253-261. https://doi.org/10.1016/j.landurbplan.2012.03.011

Birkmann J, Krings S, Renaud F (2008) Assessment of vulnerability to floods at local level with a special focus on human-environmental systems and critical infrastructures. In: Simonovic SP, Bourget PG, and Blanchard SF (Eds.) Proceedings of the 4th international symposium on flood defence Managing flood risk, reliability and vulnerability (pp. 6-8). Toronto, Ontario, Canada: institute for catastrophic loss reduction

Birkmann J, Cutter SL, Rothman DS, Welle T, Garschagen M, van Ruijven B, Pulwarty R (2015) Scenarios for vulnerability: opportunities and constraints in the context of climate change and disaster risk. Clim Change 133(1):53-68. https://doi.org/10.1007/s10584-013-0913-2

BKA (2013) Arbeitsprogramm der österreichischen Bundesregierung 2013-2018. Bundeskanzleramt, Wien

BKA (2017a) Zusammen: Für unser Österreich. Regierungsprogramm 2017 - 2022. Bundeskanzleramt, Wien

BKA (2017b) Nationales Reformprogramm Österreich. Bundeskanzleramt, Wien

Blöschl G, Hall J, Viglione A, Perdigão RAP, Parajka J, Merz B et al (2019) Changing climate both increases and decreases European river floods. Nature. https://doi.org/10.1038/s41586-019-1495-6

BMASK ed (2015) Bericht zur Lage und zu den Perspektiven des Freiwilligen Engagements in Österreich. 2. Freiwilligenbericht. Vienna: Bundesministerium für Arbeit, Soziales und Konsumenten-schutz

BMASK (2012) Nationaler Aktionsplan Behinderung 2012-2020. Bundesministerium für Arbeit, Soziales und Konsumentenschutz, Wien

BMI (2009a) Staatliches Krisen- und Katastrophenmanagement: SKKM Strategie 2020. Bundesministerium des Innern, Wien

BMI (2009b) SKKM-Strategie 2020. Bundesministerium für Inneres, Wien

BMI (2013) Staatliches Krisen- und Katastrophenschutzmanagement: Rechtliche und organisatorische Grundlagen. Bundesministerium für Inneres, Wien

BMI (2015) Wildbäche und Lawinen. Bundesministerium für Inneres, Wien

BMI (2016) Understanding Risk Austria. Bundesministerium für Inneres, Wien

BMLFUW (2006) Hochwasserschutz in Österreich. Bundesministerium für Land- und Forstwirtschaft, Umwelt und Wasserwirtschaft, Wien

BMLFUW (2009) Herausforderung Demografie: Den gesellschaftlichen Wandel zukunftsfähig gestalten. Bundesministerium für Land- und Forstwirtschaft, Umwelt und Wasserwirtschaft, Wien

BMLFUW (2011a) Anpassungsstrategien an den Klimawandel für Österreichs Wasserwirtschaft. Bundesministerium für Land- und Forstwirtschaft, Umwelt und Wasserwirtschaft, Wien

BMLFUW (2011b) Vorläufige Bewertung des Hochwasserrisikos 2011. Bundesministerium für Land- und Forstwirtschaft, Umwelt und Wasserwirtschaft, Wien.

BMLFUW (2014) Schutz. Wirkung. Lebensraum: Die Wildbach- und Lawinenverbauung. Bundesministerium für Land- und Forstwirtschaft, Umwelt undWasserwirtschaft, Wien

BMLFUW (2015) FloodRisk-Evaluation Synthesebericht. Bundesministerium für Land- und Forstwirtschaft, Umwelt und Wasserwirtschaft, Wien

BMLFUW (2016a) Nationaler Hochwasserrisikomanagementplan. Bundesministerium für Land- und Forstwirtschaft, Umwelt und Wasserwirtschaft, Wien

BMLFUW (2016b) APSFR Hochwasserrisikomanagementpläne (in total 391). Bundesministerium für Land- und Forstwirtschaft, Umwelt undWasserwirtschaft, Wien 
BMLFUW (2016c) Technische Richtlinien der Bundeswasserbauverwaltung (RIWA-T). Bundesministerium für Land- und Forstwirtschaft, Umwelt und Wasserwirtschaft, Wien

BMLFUW (2017a) Masterplan Ländlicher Raum. Aufschwung für den ländlichen Raum. Wien: Bundesministerium für Land- und Forstwirtschaft, Umwelt undWasserwirtschaft

BMLFUW (2017b) Die österreichische Strategie zur Anpassung an den Klimawandel, Teil 1 - Kontext. Bundesministerium für Land- und Forstwirtschaft,Umwelt und Wasserwirtschaft, Wien

BMLFUW (2017c) Die österreichische Strategie zur Anpassung an den Klimawandel, Teil 2 - Aktionsplan. Bundesministerium für Land- und Forstwirtschaft, Umwelt und Wasserwirtschaft, Wien

BMLFUW (2017d) Klimawandel in der Wasserwirtschaft. Bundesministerium für Land- und Forstwirtschaft, Umwelt und Wasserwirtschaft, Wien

BMNT (2018) mission 2030. Die österreichische Klima- und Energiestrategie. Bundesministerium für Nachhaltigkeit und Tourismus, Wien

BMVIT, BMFWF, BMG, BMASK, BKA (2015) Koordinierte FTI-Strategien und -Maßnahmen für Mobilität und Lebensqualität vor dem Hintergrund des demografischen Wandels. Bundesministerium für Verkehr, Innovation und Technologie, Wien

BMWFJ (2010) Energiestrategie Österreich. Bundesministerium für Wirtschaft, Familie und Jugend, Wien

Bolin B, Kurtz LC (2018) Race, class, ethnicity, and disaster vulnerability. In: Rodríguez H, Donner W, Trainor JE (eds) Handbook of disaster research. Springer, Cham, pp 181-203

Bonin H (2013) Generational accounting: theory and application. Springer, New York

Boon HJ (2014) Disaster resilience in a flood-impacted rural Australian town. Nat Hazards 71(1):683-701. https://doi.org/10.1007/s11069-013-0935-0

Wouter Botzen WJ, Van Den Bergh JCJM (2012) Monetary valuation of insurance against flood risk under climate change. Int Econ Rev 53(3):1005-1026. https://doi.org/10.1111/j.1468-2354.2012.00709.x

Botzen WJW, Aerts JCJH, van den Bergh JCJM (2009) Dependence of flood risk perceptions on socioeconomic and objective risk factors. Water Resour Res. https://doi.org/10.1029/2009WR007743

Braun V, Clarke V (2006) Using thematic analysis in psychology. Qual Res Psychol 3(2):77-101

Burningham K, Fielding J, Thrush D (2008) "It'll never happen to me": understanding public awareness of local flood risk. Disasters 32(2):216-238. https://doi.org/10.1111/j.1467-7717.2007.01036.x

IPCC (ed) (2012) Managing the risks of extreme events and disasters to advance climate change adaptation: special report of the intergovernmental panel on climate change. Cambridge University Press. https:// www.ipcc.ch/report/srex/

Cammerer H, Thieken AH (2013) Historical development and future outlook of the flood damage potential of residential areas in the Alpine Lech Valley (Austria) between 1971 and 2030. Reg Environ Change 13(5):999-1012. https://doi.org/10.1007/s10113-013-0407-9

Chakraborty J, Tobin GA, Montz BE (2005) Population evacuation: assessing spatial variability in geophysical risk and social vulnerability to natural hazards. Nat Hazards Rev 6(1):23-33. https://doi. org/10.1061/(ASCE)1527-6988(2005)6:1(23)

Cheema AR, Scheyvens R, Glavovic B, Imran M (2014) Unnoticed but important: revealing the hidden contribution of community-based religious institution of the mosque in disasters. Nat Hazards 71(3):2207-2229. https://doi.org/10.1007/s11069-013-1008-0

Cheong S-M (2018) Second homes and vulnerability after superstorm sandy in Ortley beach, New Jersey. Prof Geogr 70(4):583-592. https://doi.org/10.1080/00330124.2018.1432369

Clar C (2019) How demographic developments determine the management of hydrometeorological hazard risks in rural communities: The linkages between demographic and natural hazards research. WIREs Water. https://doi.org/10.1002/wat2.1378

Codjoe SNA, Afuduo S (2015) Geophysical, socio-demographic characteristics and perception of flood vulnerability in Accra, Ghana. Nat Hazards 77(2):787-804. https://doi.org/10.1007/s1106 9-015-1624-y

Cope MR, Lee MR, Slack T, Blanchard TC, Carney J, Lipschitz F, Gikas L (2018) Geographically distant social networks elevate perceived preparedness for coastal environmental threats. Popul Environ 39(3):277-296. https://doi.org/10.1007/s11111-017-0292-0

CoR (ed) (2016) The impact of demographic change on European regions. European Union-Committee of the Regions, Brussels

Coyle M (2015) Understanding resistance to climate change resistance. Int J Aging Hum Dev 80(1):7686. https://doi.org/10.1177/0091415015591111

Cross JA (2001) Megacities and small towns: different perspectives on hazard vulnerability. Environ Hazards 3(2):63-80. https://doi.org/10.3763/ehaz.2001.0307

Cui K, Sim T (2017) Older people's psychosocial needs in a post-disaster rural community of China: an exploratory study. Nat Hazards 85(3):1577-1590. https://doi.org/10.1007/s11069-016-2649-6 
Cutter SL, Emrich CT (2006) Moral hazard, social catastrophe: the changing face of vulnerability along the hurricane coasts. Ann Am Acad Political Soc Sci 604(1):102-112. https://doi. org/10.1177/0002716205285515

Cutter SL, Finch C (2008) Temporal and spatial changes in social vulnerability to natural hazards. Proc Natl Acad Sci 105(7):2301-2306. https://doi.org/10.1073/pnas.0710375105

Cutter SL, Boruff BJ, Shirley WL (2003) Social vulnerability to environmental hazards*. Soc Sci Q 84(2):242-261. https://doi.org/10.1111/1540-6237.8402002

Di Baldassarre G, Kooy M, Kemerink JS, Brandimarte L (2013) Towards understanding the dynamic behaviour of floodplains as human-water systems. Hydrol Earth Syst Sci 17(8):3235-3244. https:// doi.org/10.5194/hess-17-3235-2013

Di Baldassarre G, Kemerink JS, Kooy M, Brandimarte L (2014) Floods and societies: the spatial distribution of water-related disaster risk and its dynamics. WIREs Water 1(2):133-139. https://doi. org/10.1002/wat2.1015

Donner W, Rodriguez H (2008) Population composition, migration and inequality: the influence of demographic changes on disaster risk and vulnerability. Soc Forces 87(2):1089-1114. https://doi. org/10.1353/sof.0.0141

Dressler G, Müller B, Frank K, Kuhlicke C (2016) Towards thresholds of disaster management performance under demographic change: exploring functional relationships using agent-based modeling. Nat Hazards Earth Syst Sci 16(10):2287-2301. https://doi.org/10.5194/nhess-16-2287-2016

Dzialek J, Biernacki W, Bokwa A (2013) Impact of social capital on local communities? response to floods in Southern Poland. In: Neef A, Shaw R (eds) Risks and conflicts: local responses to natural disasters. Emerald Group Publishing Limited, Bingley, pp 185-205

Enarson E (2001) What women do: gendered labor in the Red River Valley flood. Glob Environ Change B Environ Hazards 3(1):1-18. https://doi.org/10.3763/ehaz.2001.0301

Enarson E, Fothergill A, Peek L (2018) Gender and disaster: foundations and new directions for research and practice. In: Rodríguez H, Donner W, Trainor JE (eds) Handbook of disaster research. Springer International Publishing, Cham, pp 205-223

Evans JR, Mathur A (2005) The value of online surveys. Internet Res 15(2):195-219. https://doi. org/10.1108/10662240510590360

Evans E, Hall J, Penning-Rowsell E, Sayers P, Thorne C, Watkinson A (2006) Future flood risk management in the UK. Proc Inst Civil Eng-Water Manag 159(1):53-61. https://doi.org/10.1680/ wama.2006.159.1.53

Fabricius C, Folke C, Cundill G, Schultz L (2007) Powerless spectators, coping actors, and adaptive comanagers: a synthesis of the role of communities in ecosystem management. Ecol Soc. https://doi. org/10.5751/ES-02072-120129

Fatemi F, Ardalan A, Aguirre B, Mansouri N, Mohammadfam I (2017) Social vulnerability indicators in disasters: findings from a systematic review. Int J Disaster Risk Reduct 22:219-227. https://doi. org/10.1016/j.ijdrr.2016.09.006

Fekete A (2009) The interrelation of social vulnerability and demographic change in Germany. Paper at the IHDP open meeting 2009, the 7 th international science conference on the human dimensions of global environmental change

Fekete A (2009) Validation of a social vulnerability index in context to river-floods in Germany. Nat Hazards Earth Syst Sci 9(2):393-403. https://doi.org/10.5194/nhess-9-393-2009

Fekete A (2018) Social vulnerability change assessment: monitoring longitudinal demographic indicators of disaster risk in Germany from 2005 to 2015. Nat Hazards 95(3):585-614. https://doi.org/10.1007/ s11069-018-3506-6 (onlinefirst)

Fekete A, Mudimu OA, Bäumer J, Brand C, Eiling C, Fehn K et al (2016) Bevölkerungsschutz im gesellschaftlichen Wandel (BigWa). Neue interdisziplinäre Ansätze und Instrumente für Einsatzkräfte und Bevölkerung. In BBK Bundesamt für Bevölkerungsschutz und Katastrophenhilfe (Ed.), Staatliche Krisen- und Notfallsvorsorge. BBK: Bonn

Fothergill A, Peek LA (2004) Poverty and disasters in the United States: a review of recent sociological findings. Nat Hazards 32(1):89-110. https://doi.org/10.1023/B:NHAZ.0000026792.76181.d9

Fuchs S, Keiler M, Zischg A (2015) A spatiotemporal multi-hazard exposure assessment based on property data. Nat Hazards Earth Syst Sci 15(9):2127-2142. https://doi.org/10.5194/nhess-15-2127-2015

Fuchs S, Röthlisberger V, Thaler T, Zischg A, Keiler M (2017) Natural hazard management from a coevolutionary perspective: exposure and policy response in the European Alps. Ann Am As Geogr 107(2):382-392. https://doi.org/10.1080/24694452.2016.1235494

Gaillard JC, Sanz K, Balgos BC, Dalisay SNM, Gorman-Murray A, Smith F, Toelupe V (2017) Beyond men and women: a critical perspective on gender and disaster. Disasters 41(3):429-447. https://doi. org/10.1111/disa.12209 
Gaillard JC, Cadag JRD, Rampengan MMF (2018) People's capacities in facing hazards and disasters: an overview. Nat Hazards. https://doi.org/10.1007/s11069-018-3519-1

Gamble JL, Hurley BJ, Schultz PA, Jaglom WS, Krishnan N, Harris M (2013) Climate change and older Americans: state of the science. Environ Health Perspect 121(1):15-22. https://doi.org/10.1289/ ehp. 1205223

Garbutt K, Ellul C, Fujiyama T (2015) Mapping social vulnerability to flood hazard in Norfolk, England. Environ Hazards 14(2):156-186. https://doi.org/10.1080/17477891.2015.1028018

Gissing A, Keys C, Opper S (2010) Towards resilience against flood risks. Aust J Emerg Manag 25(2):41-47

Glaser BG, Strauss AL (1998) Grounded theory. Strategien qualitativer Forschung, Bern

Gotham KF, Campanella R, Lauve-Moon K, Powers B (2018) Hazard experience, geophysical vulnerability, and flood risk perceptions in a postdisaster city, the case of New Orleans: flood risk perceptions in a postdisaster city. Risk Anal 38(2):345-356. https://doi.org/10.1111/risa.12830

Graif C (2016) (Un) natural disaster: vulnerability, long-distance displacement, and the extended geography of neighborhood distress and attainment after Katrina. Popul Environ 37(3):288-318. https://doi. org/10.1007/s11111-015-0243-6

Grothmann T, Reusswig F (2006) People at risk of flooding: why some residents take precautionary action while others do not. Nat Hazards 38(1):101-120. https://doi.org/10.1007/s11069-005-8604-6

Hallegatte S (2009) Strategies to adapt to an uncertain climate change. Glob Environ Change 19(2):240247. https://doi.org/10.1016/j.gloenvcha.2008.12.003

Hallegatte S, Shah A, Lempert R, Brown C, and Gill S (2012) Investment Decision Making Under Deep Uncertainty. Policy Research Working Paper 6193. World Bank. https://www.belrim.com/app/uploa ds/2014/11/1813-9450-6193.pdf

Hanger S, Linneroth-Bayer J, Surminski S, Nenciu-Posner C, Lorant A, Ionesco R, Patt A (2018) Insurance, public assistance, and household flood risk reduction: a comparative study of Austria, England, and Romania. Risk Anal 38(4):680-693. https://doi.org/10.1111/risa.12881

Haq SMA, Ahmed KJ (2017) Does the perception of climate change vary with the socio-demographic dimensions? A study on vulnerable populations in Bangladesh. Nat Hazards 85(3):1759-1785. https ://doi.org/10.1007/s11069-016-2664-7

Haque CE, Etkin D (2007) People and community as constituent parts of hazards: the significance of societal dimensions in hazards analysis. Nat Hazards 41(2):271-282. https://doi.org/10.1007/s1106 9-006-9035-8

Hardy RD, Hauer ME (2018) Social vulnerability projections improve sea-level rise risk assessments. Appl Geogr 91:10-20. https://doi.org/10.1016/j.apgeog.2017.12.019

Harries T, Penning-Rowsell E (2011) Victim pressure, institutional inertia and climate change adaptation: the case of flood risk. Glob Environ Change 21:188-197. https://doi.org/10.1016/j.gloen vcha.2010.09.002

Hauer ME, Hardy RD, Mishra DR, Pippin JS (2019) No landward movement: examining 80 years of population migration and shoreline change in Louisiana. Popul Environ 40(4):369-387. https://doi. org/10.1007/s11111-019-00315-8

He B, Huang X, Ma M, Chang Q, Tu Y, Li Q et al (2018) Analysis of flash flood disaster characteristics in China from 2011 to 2015. Nat Hazards 90(1):407-420. https://doi.org/10.1007/s11069-017-3052-7

Hiess H, Dax T, Fidlschuster L, Fischer M, Oedl-Wieser T (2017) Österreichische Regionen mit Bevölkerungsrückgang-Analysen und Handlungsempfehlungen. ÖROK, Wien

Holsti OR (1969) Content analysis for the social sciences and humanities. Addison-Wesley, Reading MA

Huang S-K, Lindell MK, Prater CS (2016) Who leaves and who stays? A review and statistical meta-analysis of hurricane evacuation studies. Environ Behav 48(8):991-1029. https://doi.org/10.1177/00139 16515578485

Hung L-S (2017) Married couples' decision-making about household natural hazard preparedness: a case study of hurricane hazards in Sarasota County, Florida. Nat Hazards 87(2):1057-1081. https://doi. org/10.1007/s11069-017-2809-3

Jachs S (2011a) Aus dem Inneren. Staatliches Krisen- und Katastrophenschutzmanagement. Fachgespräch mit Innenministerin Maria Fekter. Bundesministerium für Inneres, Wien

Jachs S (2011b) Unterschiedliche Reaktionen. Die Bedeutung sozialer Faktoren für die Warnung im Katastrophenfall. Öffentliche Sicherheit, 11-12/11: 54-55

Jachs S (2014a) Ausnahmezustand Massenevakuierung. Öffentliche Sicherheit 3-4(14):37-39

Jachs S (2014b) Nationale Risikoanalyse. Öffentliche Sicherheit 11-12/14, 30-31

Jachs S (2015a) Besondere Bedürfnisse. Öffentliche Sicherheit 5-6(15):75-76

Jachs S (2015b) Neue Herausforderungen. Öffentliche Sicherheit 3-4/15, 54-56 
Jachs S and Kreuzer S (2015) Floodrisk E(valuierung): analyse der Empfehlungen aus FRI und II und deren Umsetzungsfortschritt im Lichte der Umsetzung der Hochwasserrichtlinie. Teilbericht Katastrophenmanagement. Wien: BMI, Amt der Niederösterreichischen Landesregierung

Jachs S, Stocker R (2015) Katastrophenschutz in Österreich. kripo.at, Issue December 2015

Javadi M, Zarea K (2016) Understanding thematic analysis and its pitfall. J Client Care 1(1):34-40

Jia Z, Tian W, Liu W, Cao Y, Yan J, Shun Z (2010) Are the elderly more vulnerable to psychological impact of natural disaster? A population-based survey of adult survivors of the 2008 Sichuan earthquake. BMC Public Health. https://doi.org/10.1186/1471-2458-10-172

Jiang L, Hardee K (2011) How do recent population trends matter to climate change? Popul Res Policy Rev 30(2):287-312. https://doi.org/10.1007/s11113-010-9189-7

Jongman B, Ward PJ, Aerts JCJH (2012) Global exposure to river and coastal flooding: long term trends and changes. Glob Environ Change 22(4):823-835. https://doi.org/10.1016/j.gloenvcha.2012.07.004

Kellens W, Zaalberg R, Neutens T, Vanneuville W, De Maeyer P (2011) An analysis of the public perception of flood risk on the Belgian coast. Risk Anal Off Publ Soc Risk Anal 31(7):1055-1068. https:// doi.org/10.1111/j.1539-6924.2010.01571.x

Kiener M (2015) Enhancing disaster management preparedness for the older population in the EU. National Workshop - Report. PrepAGE project, Innsbruck

Kienholz H, Krummenacher B, Kipfer A, Perret S (2004) Aspects of integral risk management in practiceconsiderations with respect to mountain hazards in Switzerland. Österreichische Wasser- und Abfallwirtschaft 3-4:43-50

Klijn F, Samuels P, Os AV (2008) Towards flood risk management in the EU: state of affairs with examples from various European countries. Int J River Basin Manag 6(4):307-321. https://doi. org/10.1080/15715124.2008.9635358

Knocke ET, Kolivras KN (2007) Flash flood awareness in southwest Virginia. Risk Anal Off Publ Soc Risk Anal 27(1):155-169. https://doi.org/10.1111/j.1539-6924.2006.00866.x

Koks EE, Jongman B, Husby TG, Botzen WJW (2015) Combining hazard, exposure and social vulnerability to provide lessons for flood risk management. Environ Sci Policy 47:42-52. https://doi.org/10.1016/j. envsci.2014.10.013

Kõlves K, Kõlves KE, De Leo D (2013) Natural disasters and suicidal behaviours: a systematic literature review. J Affect Disord 146(1):1-14. https://doi.org/10.1016/j.jad.2012.07.037

Kuhlicke C (2010) The dynamics of vulnerability: some preliminary thoughts about the occurrence of 'radical surprises' and a case study on the 2002 flood (Germany). Nat Hazards 55(3):671-688. https://doi. org/10.1007/s11069-010-9645-z

Kuhlicke C, Scolobig A, Tapsell S, Steinführer A, De Marchi B (2011) Contextualizing social vulnerability: findings from case studies across Europe. Nat Hazards 58(2):789-810. https://doi.org/10.1007/s1106 9-011-9751-6

Kusenbach M, Simms JL, Tobin GA (2010) Disaster vulnerability and evacuation readiness: coastal mobile home residents in Florida. Nat Hazards 52(1):79-95. https://doi.org/10.1007/s11069-009-9358-3

Kyne D, Donner W (2018) Kyne-donner model of authority's recommendation and hurricane evacuation decisions: a study of hypothetical hurricane event in the Rio Grande valley, Texas. Popul Res Policy Rev 37(6):897-922. https://doi.org/10.1007/s11113-018-9492-2

Lebowitz AJ, Sato S, Aiba M (2018) Correlating post-disaster support network density with reciprocal support relation satisfaction: an elderly cohort within one year of the 2011 Japan disasters. Popul Res Policy Rev 37(6):923-939. https://doi.org/10.1007/s11113-018-9498-9

Lechowska E (2018) What determines flood risk perception? A review of factors of flood risk perception and relations between its basic elements. Nat Hazards 94(3):1341-1366. https://doi.org/10.1007/ s11069-018-3480-z

Lee Y-J (2014) Social vulnerability indicators as a sustainable planning tool. Environ Impact Assess Rev 44:31-42. https://doi.org/10.1016/j.eiar.2013.08.002

Lee D (2018) The impact of natural disasters on neighborhood poverty rate: a neighborhood change perspective. J Plan Educ Res. https://doi.org/10.1177/0739456X18769144

Lindell MK, Hwang SN (2008) Households' perceived personal risk and responses in a multihazard environment. Risk Anal 28(2):539-556. https://doi.org/10.1111/j.1539-6924.2008.01032.x

Löschner L (2018) The spatial turn in flood risk management. A case study of Austria's changing flood policies (Doctoral Thesis). University of natural resources and life sciences, Vienna (BOKU), Vienna

Löschner L, Herrnegger M, Apperl B, Senoner T, Seher W, Nachtnebel HP (2017) Flood risk, climate change and settlement development: a micro-scale assessment of Austrian municipalities. Reg Environ Change 17(2):311-322. https://doi.org/10.1007/s10113-016-1009-0

Lutz W, Muttarak R (2017) Forecasting societies' adaptive capacities through a demographic metabolism model. Nat Clim Change 7(3):177-184. https://doi.org/10.1038/nclimate3222 
Madsen H, Lawrence D, Lang M, Martinkova M, Kjeldsen TR (2014) Review of trend analysis and climate change projections of extreme precipitation and floods in Europe. J Hydrol 519:3634-3650. https:// doi.org/10.1016/j.jhydrol.2014.11.003

Maguire B (2007) Disasters and communities: understanding social resilience. Aust J Emerg Manag 22(2):5

Matsubayashi T, Sawada Y, Ueda M (2013) Natural disasters and suicide: evidence from Japan. Soc Sci Med 82:126-133. https://doi.org/10.1016/j.socscimed.2012.12.021

McGee TK, Russell S (2003) "It's just a natural way of life..." an investigation of wildfire preparedness in rural Australia. Environ Hazards 5(1):1-12. https://doi.org/10.1016/j.hazards.2003.04.001

McLeman R (2010) Impacts of population change on vulnerability and the capacity to adapt to climate change and variability: a typology based on lessons from "a hard country." Popul Environ 31(5):286316. https://doi.org/10.1007/s11111-009-0087-z

McLennan J, Birch A (2005) A potential crisis in wildfire emergency response capability? Australia's volunteer firefighters. Environ Hazards 6(2):101-107. https://doi.org/10.1016/j.hazards.2005.10.003

Merz B, Hall J, Disse M, Schumann A (2010) Fluvial flood risk management in a changing world. Nat Hazards Earth Syst Sci 10(3):509-527. https://doi.org/10.5194/nhess-10-509-2010

Meyer MA (2018) Social capital in disaster research. In: Rodríguez H, Donner W, Trainor JE (eds) Handbook of disaster research. Springer, Cham, pp 263-286

Mishra S, Mazumdar S, Suar D (2010) Place attachment and flood preparedness. J Environ Psychol 30(2):187-197. https://doi.org/10.1016/j.jenvp.2009.11.005

Moody HR (2015) Overcoming objections by elders to action on climate change. Int J Aging Human Dev 80(1):64-75. https://doi.org/10.1177/0091415015591110

Moreno J, Shaw D (2018) Women's empowerment following disaster: a longitudinal study of social change. Nat Hazards 92(1):205-224. https://doi.org/10.1007/s11069-018-3204-4

Muttarak R, Pothisiri W (2013) The role of education on disaster preparedness: case study of 2012 indian ocean earthquakes on Thailand's Andaman coast. Ecol Soc. https://doi.org/10.5751/ES-06101-18045 1

Nordbeck R, Steurer R, Löschner L (2019) The future orientation of Austria's flood policies: from flood control to anticipatory flood risk management. J Environ Plan Manag. https://doi.org/10.1080/09640 568.2018 .1515731

O'Hare P, White I (2018) Beyond 'just' flood risk management: the potential for-and limits to-alleviating flood disadvantage. Reg Environ Change 18(2):385-396. https://doi.org/10.1007/s10113-017-1216-3

OECD (2016) Society at a glance 2016. OECD, Paris

OECD. (2019). OECD Glossary of statistical terms-population change definition. https://stats.oecd.org/ glossary/detail.asp?ID=6638. Accessed 8 Aug 2019

ÖROK (1986) ÖROK-Empfehlung Nr. 20: Empfehlungen zur besseren Berücksichtigung von Naturgefahren in der Raumplanung. ÖROK, Wien

ÖROK (2005) ÖROK-Empfehlung Nr. 52 zum präventiven Umgang mit Naturgefahren in der Raumordnung (Schwerpunkt Hochwasser). ÖROK, Wien

ÖROK (2011) Österreichisches Raumentwicklungskonzept ÖREK 2011. ÖROK, Wien

ÖROK (2015a) ÖROK-Regionalprognosen 2014-2030, Teil 1: Bevölkerung. Schriftenreihe Nr. 196/I. Österreichische Raumordnungskonferenz, Wien

ÖROK (2015b) ÖROK-Empfehlung Nr. 54: Risikomanagement für gravitative Naturgefahren in der Raumplanung. ÖROK, Wien

ÖROK (2017) ÖROK-Empfehlung Nr. 57 zum Hochwasserrisikomanagement. ÖROK, Wien

Paprotny D, Morales-Nápoles O, Jonkman SN (2018) HANZE: a pan-European database of exposure to natural hazards and damaging historical floods since 1870. Earth Syst Sci Data 10(1):565-581. https ://doi.org/10.5194/essd-10-565-2018

Paxson C, Rouse CE (2008) Returning to New Orleans after Hurricane Katrina. Am Econ Rev 98(2):38-42. https://doi.org/10.1257/aer.98.2.38

Pesaresi M, Ehrlich D, Kemper T, Siragusa A, Florczyk A, Freire S, Corbane C (2017) Atlas of the human planet 2017: global exposure to natural hazards. Publications Office of the European Union, Luxemburg

Phillips BD, Metz WC, Nieves LA (2005) Disaster threat: preparedness and potential response of the lowest income quartile. Environ Hazards 6(3):123-133. https://doi.org/10.1016/j.hazards.2006.05.001

Poljanšek K, Marín Ferrer M, De Groeve T, Clark I (eds) (2017) Science for disaster risk management 2017 : knowing better and losing less. Publications Office of the European Union, Luxemburg

Prior T, Eriksen C (2013) Wildfire preparedness, community cohesion and social-ecological systems. Glob Environ Change 23(6):1575-1586. https://doi.org/10.1016/j.gloenvcha.2013.09.016 
Qasim S, Nawaz Khan A, Prasad Shrestha R, Qasim M (2015) Risk perception of the people in the flood prone Khyber Pukhthunkhwa province of Pakistan. Int J Disaster Risk Reduct 14:373-378. https:// doi.org/10.1016/j.ijdrr.2015.09.001

Quezada-Hofflinger A, Somos-Valenzuela MA, Vallejos-Romero A (2017) Response time to flood events using a social vulnerability index (ReTSVI). Nat Hazards Earth Syst Sci Discuss. https://doi. org/10.5194/nhess-2017-395

Munich Re (2019) NatCatService. NatCatService. https://natcatservice.munichre.com/. Accessed 27 May 2019

Reusswig F, Grothmann T (2004) Präventiver Hochwasserselbstschutz von Privathaushalten und Unternehmen. In: Merz B, Apel H (eds) Risiken durch Naturgefahren in Deutschland: Abschlussbericht des BMBF-Verbundprojektes Deutsches Forschungsnetz Naturkatastrophen (DFNK). GeoForschungsZentrum, Potsdam, pp 93-106

Roth F, Herzog M, Giroux J, Prior T (2014) Trendanalyse Bevölkerungsschutz 2025. Chancen und Herausforderungen aus den Bereichen Umwelt, Technologie und Gesellschaft. Center for Security Studies (CSS), ETH Zürich

Rufat S, Tate E, Burton CG, Maroof AS (2015) Social vulnerability to floods: review of case studies and implications for measurement. Int J Disaster Risk Reduct 14:470-486. https://doi.org/10.1016/j. ijdrr.2015.09.013

Sadri AM, Ukkusuri SV, Lee S, Clawson R, Aldrich D, Nelson MS et al (2018) The role of social capital, personal networks, and emergency responders in post-disaster recovery and resilience: a study of rural communities in Indiana. Nat Hazards 90(3):1377-1406. https://doi.org/10.1007/s1106 9-017-3103-0

Sakakibara H, Murakami H, Esaki S, Mori D, Nakata H (2008) Modeling households' decisions on reconstruction of houses damaged by earthquakes-Japanese case study. Nat Hazards 44(2):293303. https://doi.org/10.1007/s11069-007-9134-1

Salzburg L (2013) Aktionsprogramm Hochwasserschutz 2018. - Bundeswasserbauverwaltung beim Amt der Salzburger Landesregierung, Salzburg

Schipfer RK (2005) Der Wandel der Bevölkerungsstruktur in Österreich-Auswirkungen auf Regionen und Kommunen. OIF-Paper 51/2005. Wien: Österreichisches Institut für Familienforschung

Scolobig A, De Marchi B, Borga M (2012) The missing link between flood risk awareness and preparedness: findings from case studies in an Alpine region. Nat Hazards 63(2):499-520. https://doi. org/10.1007/s11069-012-0161-1

Shah AA, Ye J, Abid M, Khan J, Amir SM (2018) Flood hazards: household vulnerability and resilience in disaster-prone districts of Khyber Pakhtunkhwa province, Pakistan. Nat Hazards 93(1):147165. https://doi.org/10.1007/s11069-018-3293-0

Shijin W, Dahe Q (2015) Mountain inhabitants' perspectives on climate change, and its impacts and adaptation based on temporal and spatial characteristics analysis: a case study of Mt. Yulong Snow Southeastern Tibetan Plateau. Environ Hazards 14(2):122-136. https://doi.org/10.1080/17477 891.2014.1003776

Steinführer A, Kuhlicke C (2007) Social vulnerability and the 2002 flood. Country report Germany (Mulde River). FLOODsite Project, Report Number T11-07-08

Ständiges Sekretariat der Alpenkonvention (2015) Demographischer Wandel in den Alpen. Alpconv, Innsbruck

Stojanov R, Duží B, Daněk T, Němec D, Procházka D (2015) Adaptation to the impacts of climate extremes in central Europe: a case study in a rural area in the Czech Republic. Sustainability 7(9):12758-12786. https://doi.org/10.3390/su70912758

Strümpel C, Hackl C, Stickler M, Wild M, Usmiani I, Poljak S, Juen B (2016) Verbesserung von Katastrophenvorsorge und -management für die ältere Bevölkerung in der EU-Empfehlungen. Österreichisches Rotes Kreuz, Kroatisches Rotes Kreuz, Universität Innsbruck, Wien

Szewrański S, Świąder M, Kazak JK, Tokarczyk-Dorociak K, van Hoof J (2018) Socio-environmental vulnerability mapping for environmental and flood resilience assessment: the case of ageing and poverty in the city of Wrocław, Poland: socio-environmental vulnerability mapping in Wrocław Poland. Integr Environ Assess Manag 14(5):592-597. https://doi.org/10.1002/ieam.4077

Terpstra T, Lindell MK (2013) Citizens' perceptions of flood hazard adjustments: an application of the protective action decision model. Environ Behav 45(8):993-1018. https://doi.org/10.1177/00139 16512452427

Thaler T, Löschner L, Hartmann T (2017) The introduction of catchment-wide co-operations: scalar reconstructions and transformation in Austria in flood risk management. Land Use Policy 68:563573. https://doi.org/10.1016/j.landusepol.2017.08.023 (Supplement C) 
Thieken AH, Kreibich H, Müller M, Merz B (2007) Coping with floods: preparedness, response and recovery of flood-affected residents in Germany in 2002. Hydrol Sci J 52(5):1016-1037. https:// doi.org/10.1623/hysj.52.5.1016

Thieken A, Kienzler S, Kreibich H, Kuhlicke C, Kunz M, Mühr B et al (2016) Review of the flood risk management system in Germany after the major flood in 2013. Ecol Soc. https://doi.org/10.5751/ ES-08547-210251

Thistlethwaite J, Henstra D, Brown C, Scott D (2018) How flood experience and risk perception influences protective actions and behaviours among Canadian homeowners. Environ Manage 61(2):197-208. https://doi.org/10.1007/s00267-017-0969-2

Thomlinson R (1965) Population dynamics: causes and consequences of world demographic change. Random House, New York

Tibbits A, Whittaker J (2007) Stay and defend or leave early: policy problems and experiences during the 2003 Victorian bushfires. Environ Hazards 7(4):283-290. https://doi.org/10.1016/j.envha z.2007.08.001

Tompkins EL, Hurlston L-A, Poortinga W (2009) Foreignness as a constraint on learning: the impact of migrants on disaster resilience in small islands. Environ Hazards 8(4):263-277. https://doi. org/10.3763/ehaz.2009.0018

Tragaki A, Gallousi C, Karymbalis E (2018) Coastal hazard vulnerability assessment based on geomorphic, oceanographic and demographic parameters: the case of the Peloponnese (southern Greece). Land 7(2):56. https://doi.org/10.3390/land7020056

Tyler J, Sadiq AA (2018) Friends and family vs. government: who does the public rely on more to prepare for natural disasters? Environ Hazards 17(3):234-250. https://doi.org/10.1080/17477891.2018.14252 04

UN (ed) (2015) World population ageing report. United Nations, New York

Vaismoradi M, Turunen H, Bondas T (2013) Content analysis and thematic analysis: implications for conducting a qualitative descriptive study. Nurs Health Sci 15:398-405

van Herk S, Rijke J, Zevenbergen C, Ashley R (2015) Understanding the transition to integrated flood risk management in the Netherlands. Environ Innov Soc Transit 15:84-100. https://doi.org/10.1016/j. eist.2013.11.001

Villegas J, Matyas C, Srinivasan S, Cahyanto I, Thapa B, Pennington-Gray L (2013) Cognitive and affective responses of Florida tourists after exposure to hurricane warning messages. Nat Hazards 66(1):97116. https://doi.org/10.1007/s11069-012-0119-3

Whitehead JC, Edwards B, Van Willigen M, Maiolo JR, Wilson K, Smith KT (2001) Heading for higher ground: factors affecting real and hypothetical hurricane evacuation behavior. Environ Hazards 2(4):133-142. https://doi.org/10.3763/ehaz.2000.0219

Wisbauer A, Kausl A, Marik-Lebeck S, Venningen-Fröhlich H (2013) Multilokalität in Österreich Regionale und soziodemographische Struktur der Bevölkerung mit Neben-wohnsitz(en). Statistische Nachrichten, March 2013, 196-216

Wisner B, Blaikie P, Cannon T, Davis I (2003) At risk: natural hazards, people's vulnerability and disasters, 2nd edn. Routledge, London

WLV (ed) (2018) Wildbach- und Lawinenkataster. Wildbach- und Lawinenverbauung

Zaalberg R, Midden C, Meijnders A, McCalley T (2009) Prevention, adaptation, and threat denial: flooding experiences in the Netherlands. Risk Anal Off Publ Soc Risk Anal 29(12):1759-1778. https://doi.org/ 10.1111/j.1539-6924.2009.01316.x

Publisher's Note Springer Nature remains neutral with regard to jurisdictional claims in published maps and institutional affiliations. 